تحليل قابليت اطمينان سنگحِين طراحى در اطراف يايه پِل در شرايط همبستخى بين فراسنجههاى هيدروليكى

مجتبى كريمائى طبر ستانى "

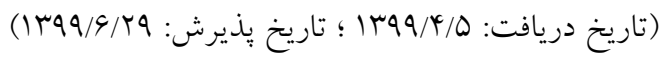

جكيده

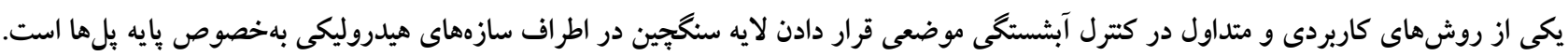

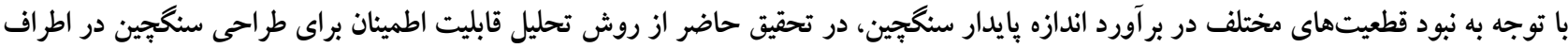

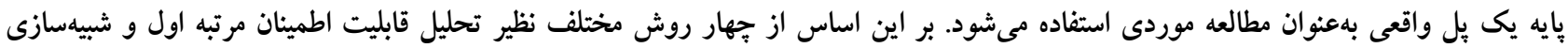

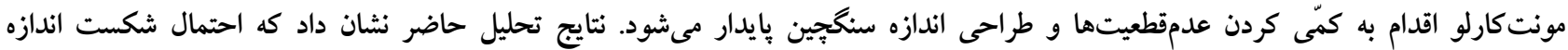

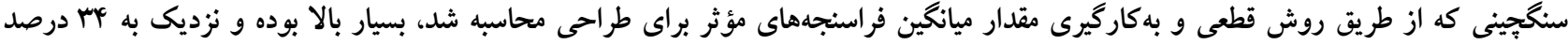

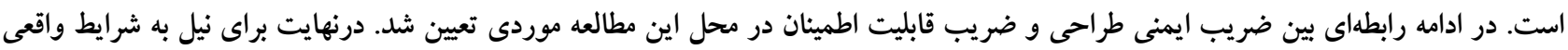

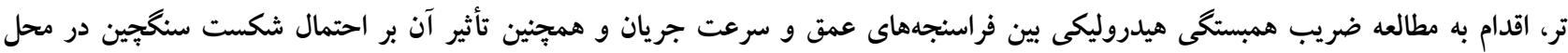

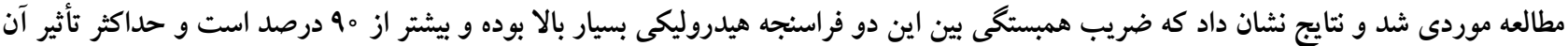

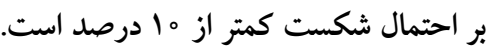

وازههاى كليدى: آبشستخى، بِيه بِل، سنگجين، قابليت اطمينان مرتبه اول، ضريب همبستى

1. كُوه مهندسى زئوتكنيك و آب، دانشكده مهندسى عمران، دانشگاه تربيت دبير شهيد رجايى، لويزان، تهران، ايران

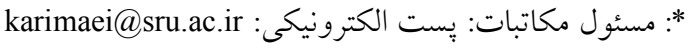




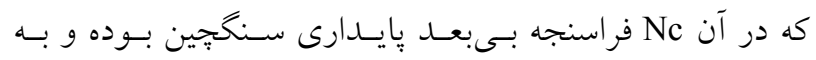
صورت زير تعريف مىشود:

$N_{c}=\rho \cdot U^{2} /\left(\rho_{s}-\rho\right) \cdot g \cdot d_{50}$

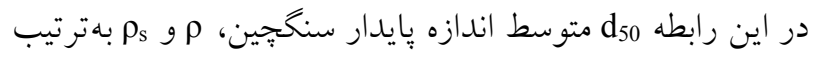

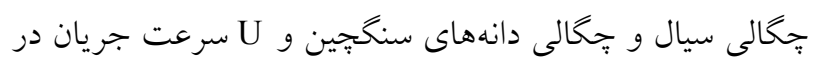
بالادست محل بايه يل هستند.

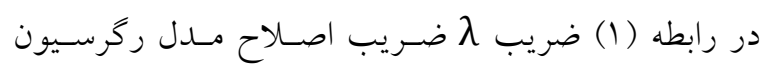

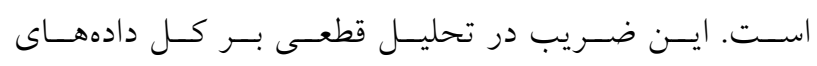

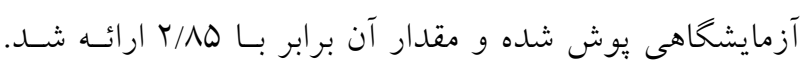

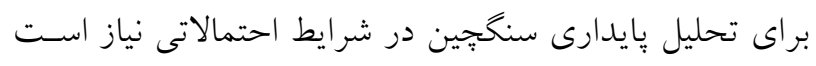

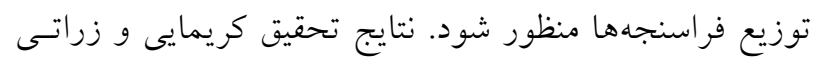

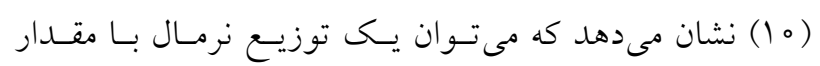

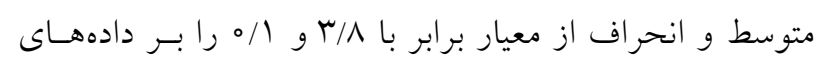
آزمايشخاهى برازش داد. ساير فراسنجههاى رابطه (1) شامل ضـريب تصسحيح عمـق

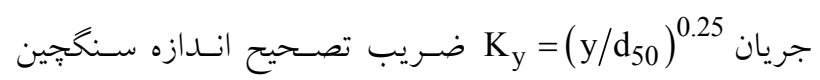
, K و ضريب اصلاح زاويه برخورد جريان بـ

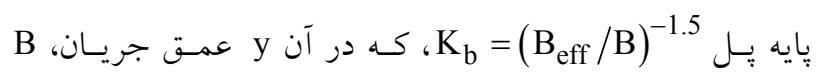

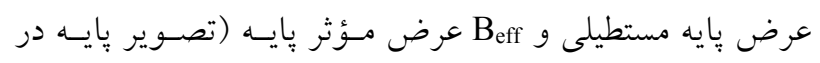

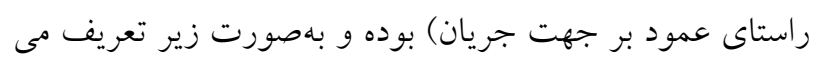

$B_{\text {eff }}=B \times(1-\operatorname{Sin} \theta)+L \times \operatorname{Sin} \theta$

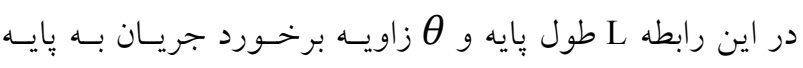
مستطيلى هستند. لازم به ذكر است در شرايطى كه بايه دايسرهاى

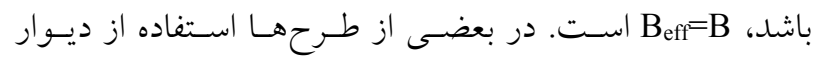

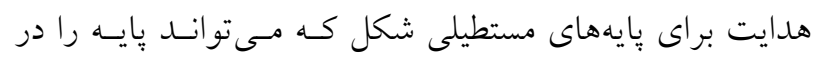

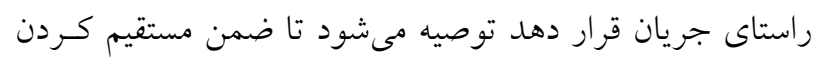

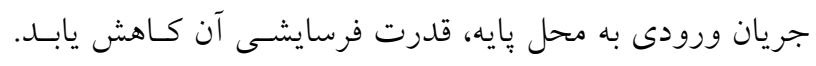

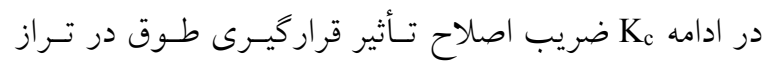

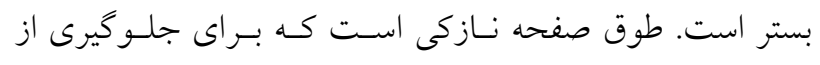

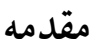

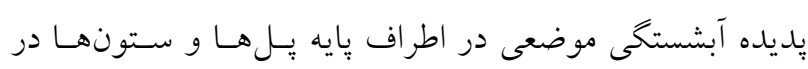

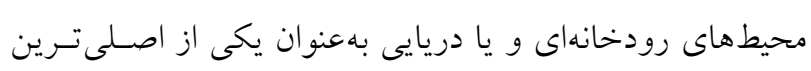

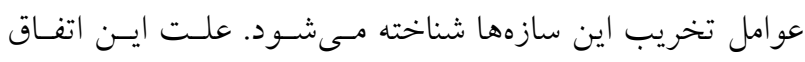
تغيير شديد الكوى جريان در بيرامون سازه است. مطالعات نشان

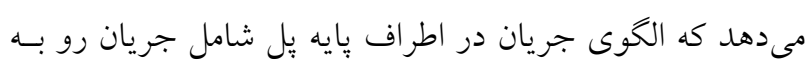

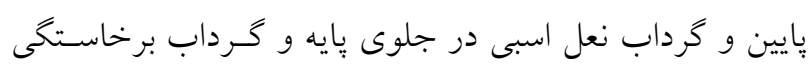

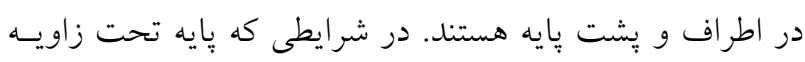

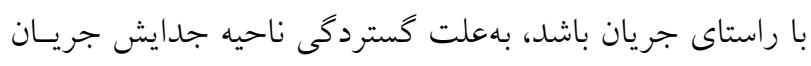

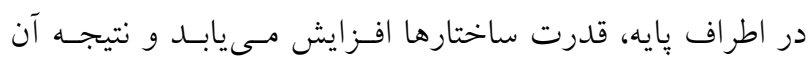
افزايش عمق و گستردخى حفره آبشستخى مى دشود.

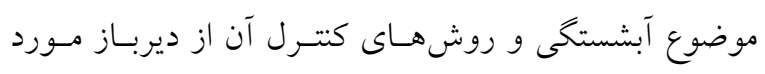
توجه يُزوهشخر ان مختلف بوده است. تفــرجنسوروز و همكـاران

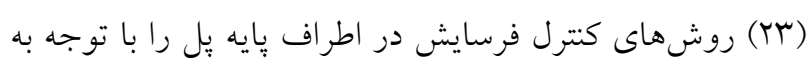
محل نصب تجهيزات كتترل آبشستكى در جهار قسمت مختلف:

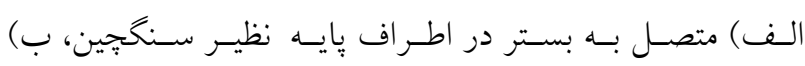

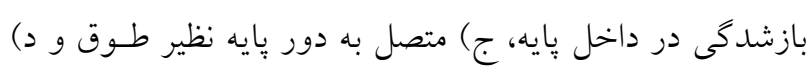
انواع متفاوت ديخر تقسيم مى كنند.

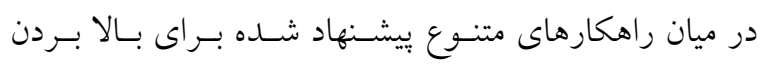

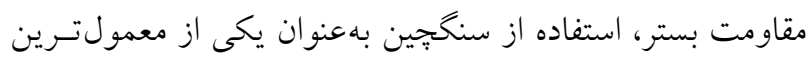

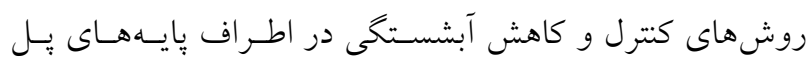

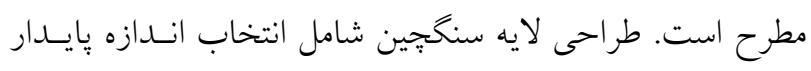

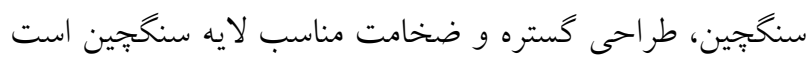

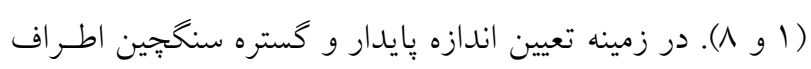

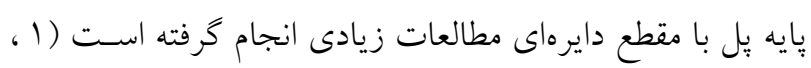

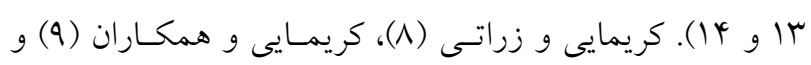

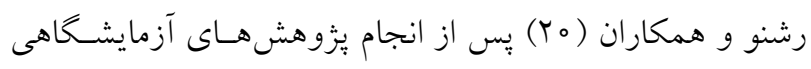

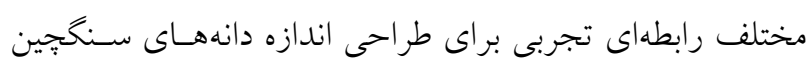

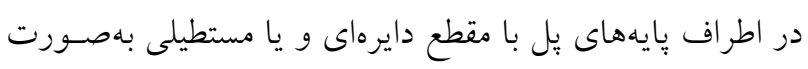

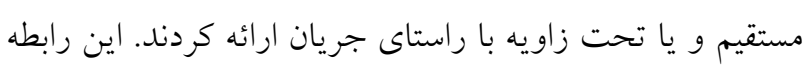

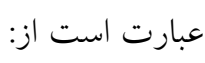

$\mathrm{N}_{\mathrm{c}}=\lambda \times \mathrm{K}_{\mathrm{y}} \times \mathrm{K}_{\mathrm{d}} \times \mathrm{K}_{\mathrm{b}} \times \mathrm{K}_{\mathrm{c}} \times \mathrm{K}_{\mathrm{u}} \times \mathrm{K}_{\mathrm{g}}$ 


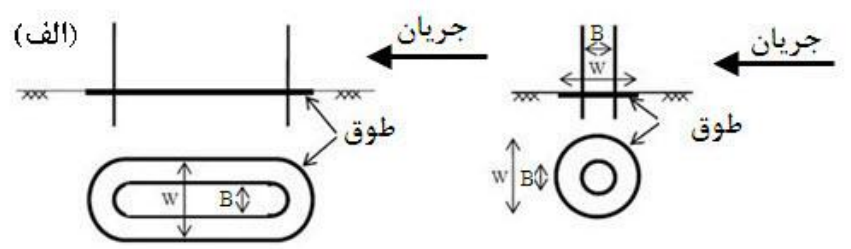

(ب)

جريان

11111

11

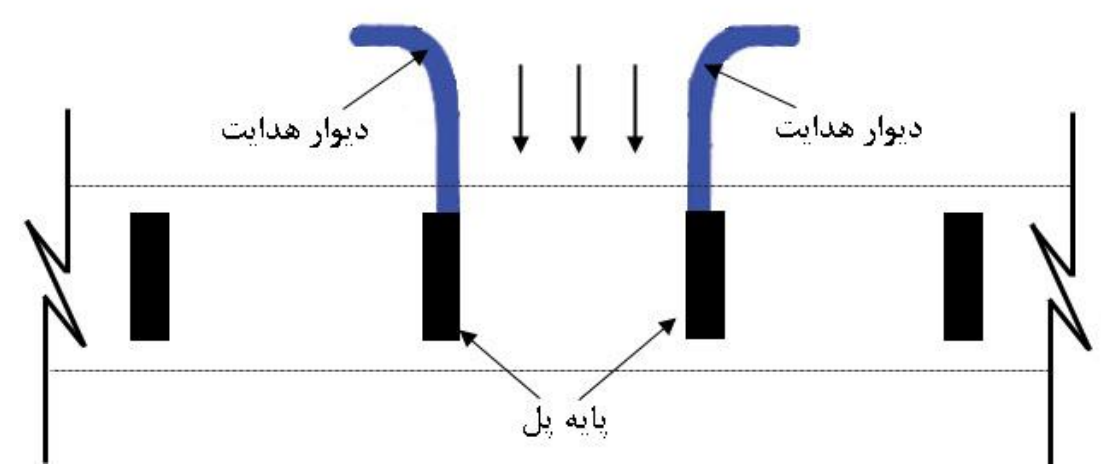

شكل ا. تركيب سنگحِين با سازههاى كنترل آبشستخى مختلف: الف) طوق و ب) ديوار هدايت

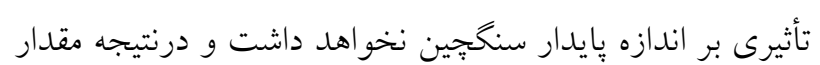

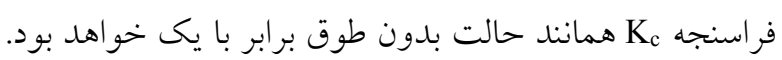

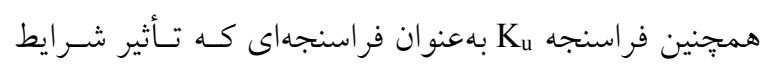

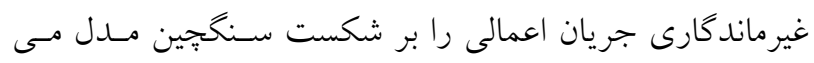

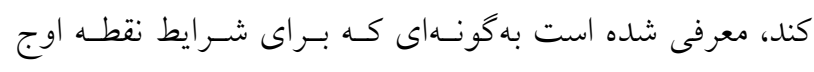

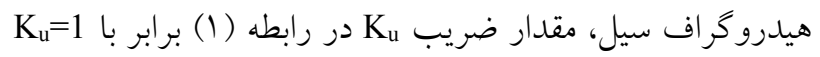

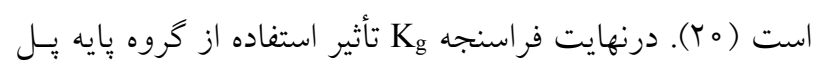

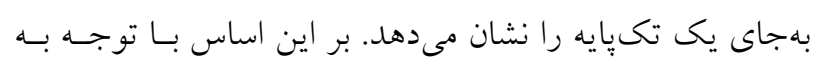

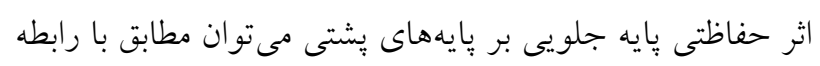

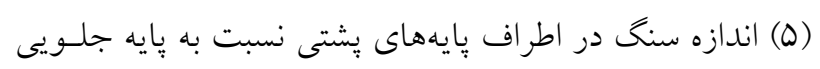

$$
\text { را كاهش داد: }
$$
$\mathrm{K}_{\mathrm{g}}= \begin{cases}1 & 1^{\text {st }} \text { pier } \\ 1.086 \times(\mathrm{G} / \mathrm{B})^{-0.225} \times\left(\mathrm{B} / \mathrm{d}_{50}\right)^{0.259} \times(\mathrm{y} / \mathrm{B})^{-0.035} & 2^{\text {nd }} \text { pier } \\ 0.982 \times(\mathrm{G} / \mathrm{B})^{-0.176} \times\left(\mathrm{B} / \mathrm{d}_{50}\right)^{0.345} \times(\mathrm{y} / \mathrm{B})^{-0.049} & 3^{\text {rd }} \text { pier }\end{cases}$

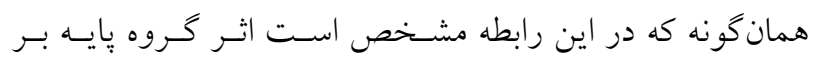

اثرهاى جريان رو به پايين و گرداب نعل اسبى در اطـراف پايـهـ يل نصب مى شود (شكل ()). كارايى طوق تابعى از ابعاد و تــراز

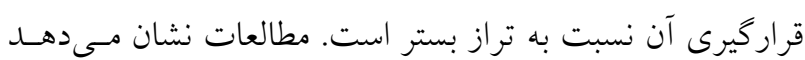
كه بهترين و اقتصادى ترين شرايط براى حالتى است كـه انــازه

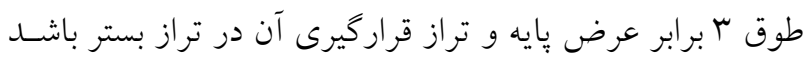
(9). در اين شرايط مقدار اين ضريب عبارت است از: $\mathrm{K}_{\mathrm{c}}=\left\{\begin{array}{l}\text { With Collar } \begin{cases}1.6 & \mathrm{~B}_{\text {eff }} / \mathrm{B}<1.7 \\ 1.0 & \mathrm{~B}_{\text {eff }} / \mathrm{B} \geq 1.7\end{cases} \\ \text { Without Collar } \rightarrow 1\end{array}\right.$

در واقـع در شـر ايطى كـه B Beff

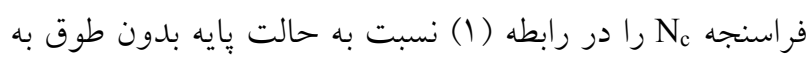

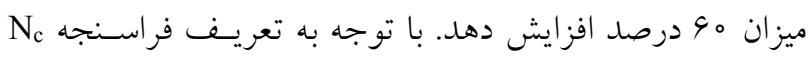

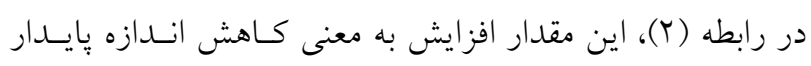

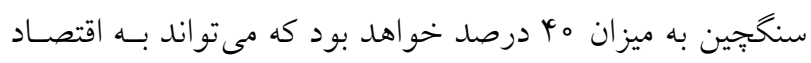

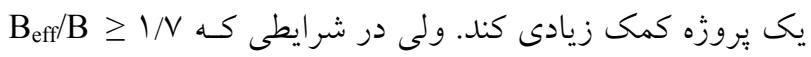

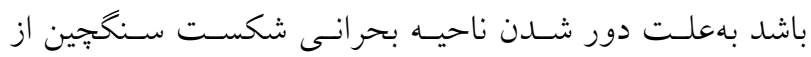

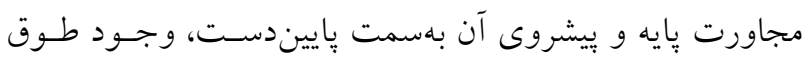


اين رهيافت جديد مسير طراحى ها در مهندسى آينده باشد و بـه مرور جايكزين روشهاى قطعى كالسيك موجود در آييننامـهـهـاى فعلى شـود. در علــم هيـدروليكى ايسن موضـوع اهميـت دوجندان دارد جِرا كه ماهيـت بارهــاى اعمـالى بـر سـازه نظيـر سيلاب و باد و يا بديدههاى مؤثر بر عملكرد سازه نظيـر حمـل بـ تهر رسوب بسيار غير قطعى هستند و در صورت طراحسى سـازه بـر اساس معيارهاى روش هاى قطعى (استفاده از ضريب اطمينـان)، اين امكان وجود دارد كه به طرحى با ايمنى بيش از حد بالا و يا يايين دست يافت. به اين ترتيب ارائسه رهيافتتهـاى جديـــ در علوم مهندسى براى اعمال عدم قطعيت ها در طراحىها اجتنـاب نايدير است. تلاشى كه در سالهاى اخير بهاشــات مـورد توجـهـ يزوهشخران قرار كرفته است و نتيجه اين تلاشها ارائسه روشهاى تحليل قابليت اطمينان و ريسك-يايه است كه مبناى آنها به كارگيرى علم احتمالات در طراحى اسـت. در مسـائل مهندسىى هيدروليك عدم قطعيتهاى موجود در دادها و تئورىهـا، هـم در مرحله تحليل و هم طراحى، منجر به لزوم اسـتفاده از روش-

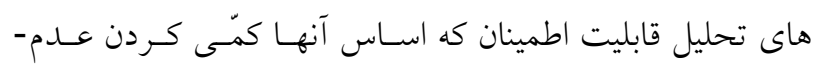
قطعيتهاى موجود در طراحى سازههـا اسـت (N|)، مسى شــود.

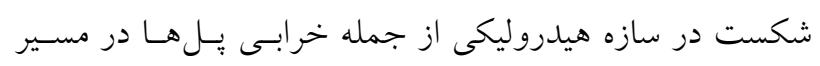

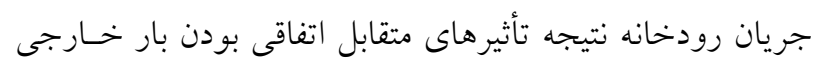
و عدمقطعيتهاى مختلـف در تحليـل، طراحسى، سـاخت و بـه كار گيرى سازه است.

جانسون و داى (ه) يك روش احتمالاتى براى تعيين عمـق

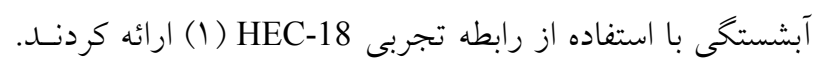
آنها در تحقيق خود اثر عمق قرارگيرى يى و همجنين عمر مفيد سازه را بر قابليت اطمينان پايدارى يك نمونه يـل واقعى مـورد بررسـى قــرار دادنــــ. موزاميـل و همكــاران (IV) يـك مـــل احتمالاتى بر اساس تحليل قابليـت اطمينـان و ارزيـابى ريسـى براى محاسبه عمق آبشستخى در اطراف پايههاى بِل ارائه كردند. در اين تحقيق كه اثر غيريكنواختى دانههاى رسوب نيـز درنظـ Fرفتـهـ شـده اسـت از روش قابليـت اطمينـان مرتبـه اول First Order Reliability Method (FORM)

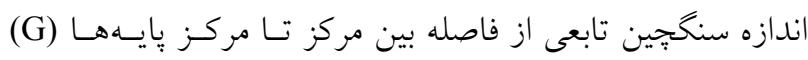
است. به اين ترتيب با توجه به مقدار فراسـنجه Kو، انسازه لازم براى سنخ در اطراف هر يايه در گروه يايه قابل محاسبه خواهد بود. در مطالعـه حاضــر از رابطــه (1) بــراى تحليـل :ايــدارى

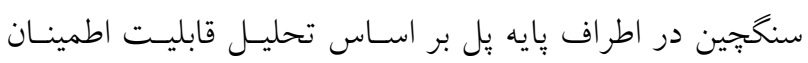

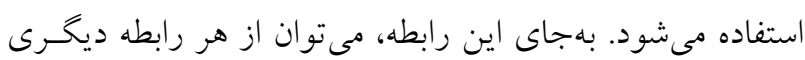
در مراجع استفاده كرد.

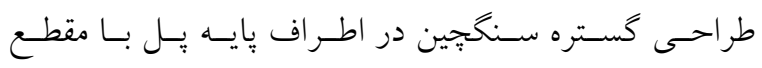
مستطيلى در دو حالـت محافظـت شـده توسـط طـوق و بــدون طوق، توسط مشاهير و همكاران (19) مورد مطالعه قـرار كرفتـه

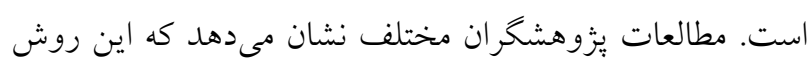

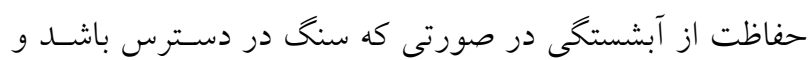

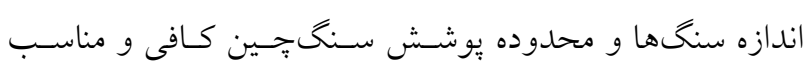
طرح شده باشد، روشى بسيار اقتصادى و مقرون بهصرفه اسـت

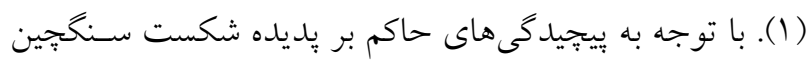

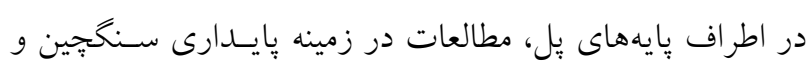
ارائه روشهاى طراحى مناسب بيشتر آزمايشخاهى و با استغاده از مدلهاى فيزيكى انجام شده است. در شرايط آب زلال درصورتى كه ضخامت و كستره مناسب بـر اى سـنخجين انتخـاب شـود، تنهـا عامـل مهـم در يايسـارى

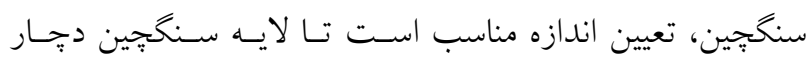
شكست برشى ناشى از نيروهاى جريان بر دانههاى سـنـ

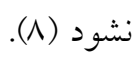
به تازگى موضـوع وِيــارى و احتمــال شكسـت سـازههـاى مهندسى با توجه به ماهيت غيرقطعى بارهاى اعمالى به سازههـا

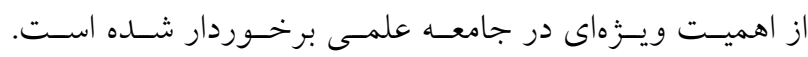
موضوعى كه در تحليل هاى قطعى كمتر مـورد توجسه قـرار مسى لـ بـ

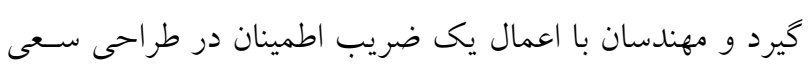
در اعمال اثرهاى عدم قطعيت در طراحى سـازه دارنـــ. بـهـ ايسن ترتيب در طراحى بـه روش قطعى، اطلاعـاتى در مـورد ميـزان هايدارى و ايمنى سازهها در دسترس نخواهد بود. بهنظر مىرسد 
شكست را كاهش داد. كريمايى (Y T) اقدام به مطالعه بر بايدارى

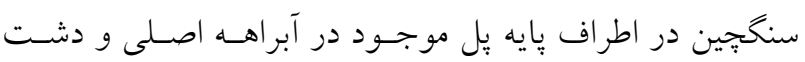

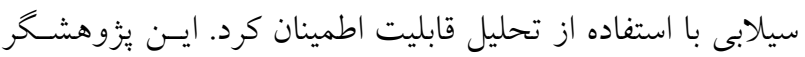

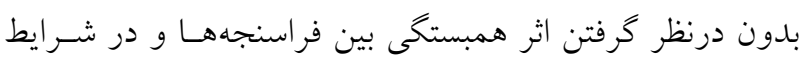

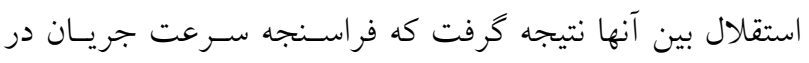
آبراهل بيشترين تأثير را بر تغيير قابليت اطمينان اندازه سـنخجينين

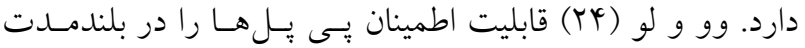
ناشى از يديده آبشستخى مورد بررسى قرار دادند. ايشان اثر ايسن يديلده را روى نشست و همجنين ظرفيـت بـاربرى :ـلـ مطالعـه

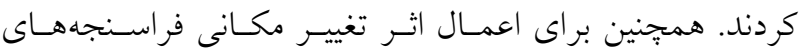
مقاومتى خاك از روش MCST استفاده كردند. نتايج اين تحقيق

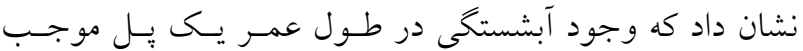
افزايش احتمال شكست آن ناشى از افزايش نشست و يا كاهش ظرفيت باربرى مىشود. مطالعـات ديخــى (9 ، 19 ، r T و TQ

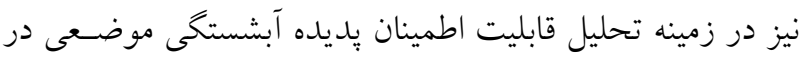
اطراف بايه يل ارائه شده است.

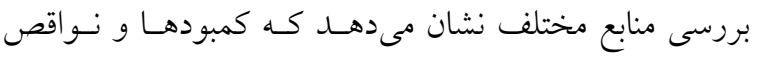

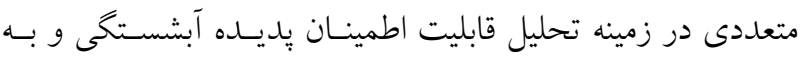

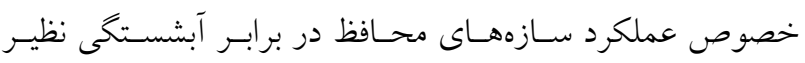

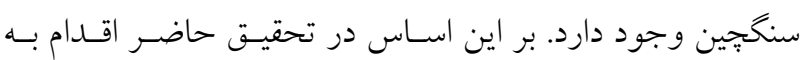

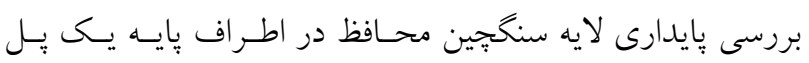
واقعى (بلكمونت نيوزيلند) با استفاده از تحليـل قابليـت اطمينـان First Oder Second مس شـود. در ايسن راستا از روشهـاى FCST و FORM Moment (FOSM) ارتباط بـين شـاخص اعتماديـــيرى و ضـريب اطمينـان در روش قطعى نيز مورد مطالعه قرار مى گيرد و درنهايت با محاسبه ضر ايب ونسب

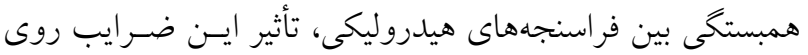
قابليت اطمينان بايدارى سنگحهين مورد مطالعه قرار مى گيرد.

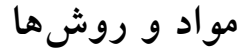
روشهاى انجام تحليل قابليت اطمينان

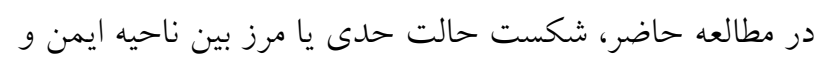

اين يزوهشخران با انجام تحليل حساسيت نشان دادند كه در بين

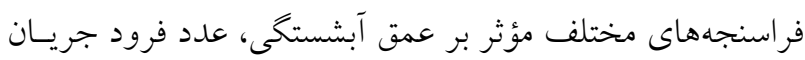

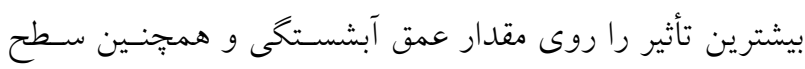

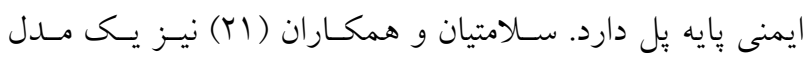

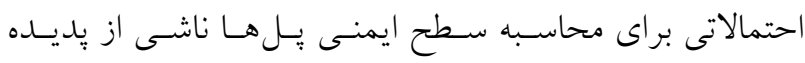

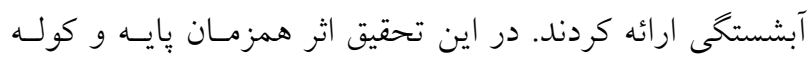

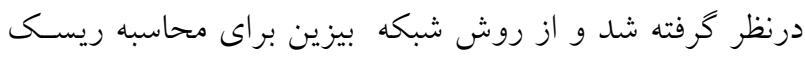

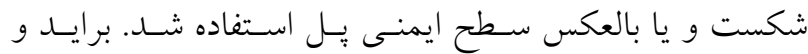

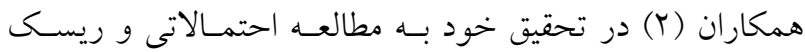

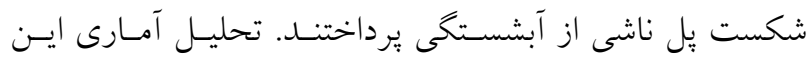
يزوهشكران روى شكست يلهاى موجود در آمريكا نشـان مسى دهد كه احتمال شكست ساليانه يك بِل ناشى از آبشستكى برابر

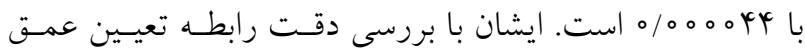

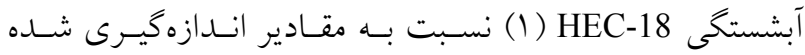
واقعى و يذذيرش ريسـى قابـل قبـول، ضـريب اطمينـان لازم را

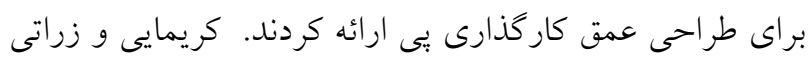
(0) اقدام به ارائه يكى روش احتمـالاتى بـر اى محاسـبه انــازه

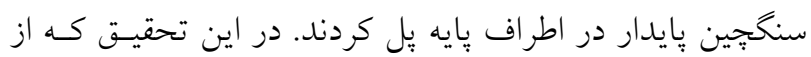

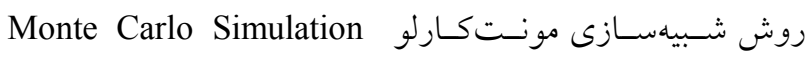
Technique (MCST)

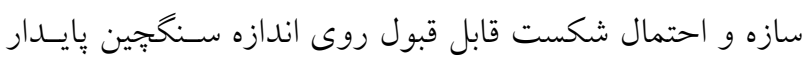

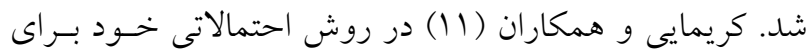

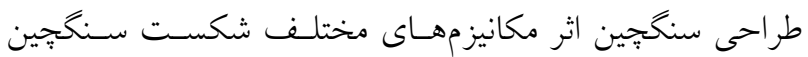

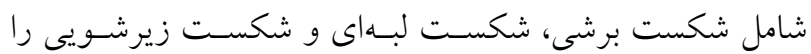

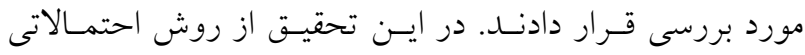

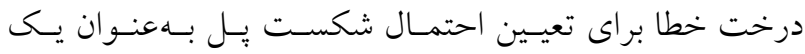
سيستم (احتمال شكست سيستم) استفاده شد. نتايج اين تحقيـق لـ لـ

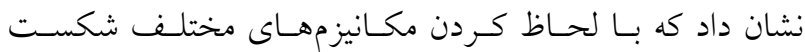

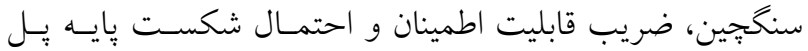
نسبت به حالت لحاظ كردن هر يك از مكانيزمها به تنهايى تغيير زيادى مى كند مخر اينكه با انتخــاب انــازههــاى مناسـب بـراى

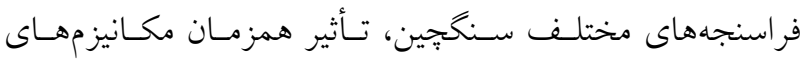


كه سهم بزركى در بيشرفت اين موضوع و ارائه روشهاى بهتـر

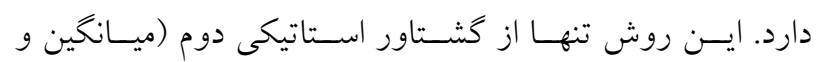

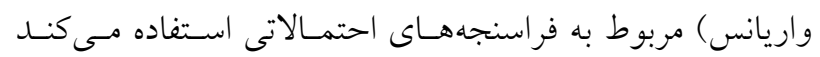

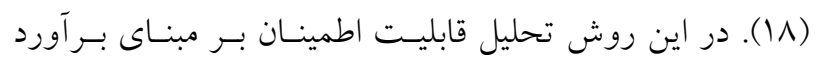

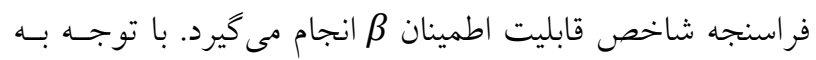

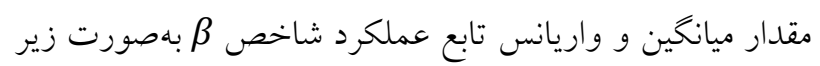

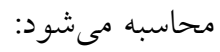
$\beta=\frac{\mu_{\mathrm{z}}}{\sigma_{\mathrm{z}}}$

كه در آن فراسنجههاى $\mu_{z}$ و با استفاده از بسط سـرى تيلـور

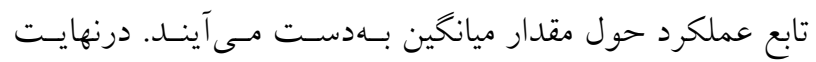

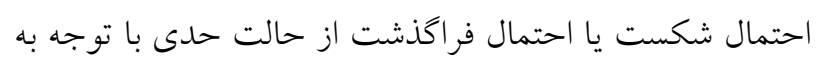
توزيع نرمال استاندارد بهصورت زير محاسبه مىشود: $\mathrm{P}_{\mathrm{f}}=\Phi(-\beta)$

كه در آن P احتمال شكست و () تابع تجمعى توزيع نرمـال

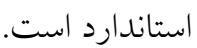

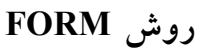

در اين روش فراسنجه م كه بهصـورت حســاقل فاصـله از مبـدأ

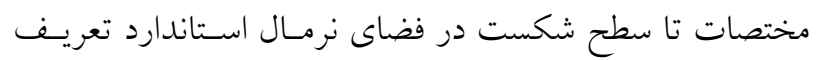
مىشود، از طريق يك مسئله بهينهسازى با قيد محدوديت بـراى

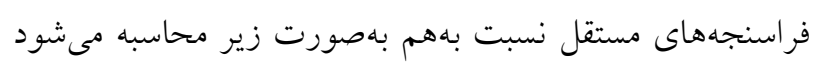

Minimize $\quad \beta(\mathrm{z})=\left(\mathrm{X}^{\prime \mathrm{T}} \mathrm{X}^{\prime}\right)^{1 / 2}$

Subject to $\mathrm{g}\left(\mathrm{X}^{\prime}\right)=0$

كه در آن g(X') تابع حالت حسـى در فضـاى نرمـال استاندارد

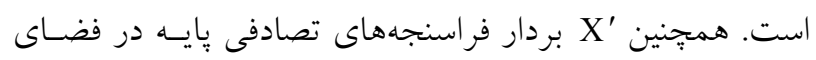

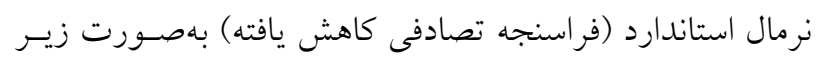
$\mathrm{X}^{\prime}=(\mathrm{X}-\mu) / \sigma$

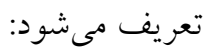
كـه در آن Xر Xراسـنجه نرمـال اسـتاندارد بـا ميـانخين صـفر و

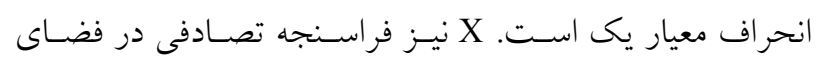

نايمن در فضاى فراسنجههاى مؤثر بر طراحى بهصسورت بيشـتر

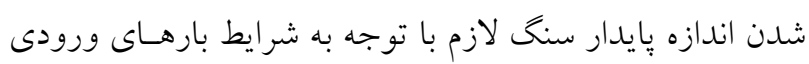
نسبت به اندازه سنگ طراحى تعريف مىشود. درنتيجه احتمـال

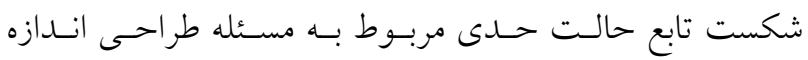

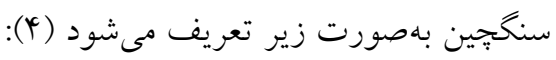
$\mathrm{P}_{\mathrm{f}}=\mathrm{P}[\mathrm{g}(\mathrm{X}) \leq 0]$

كه در آن g(X) تابع حالت حدى سنخگين و X Xردار فراسـنجه

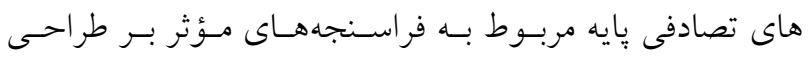

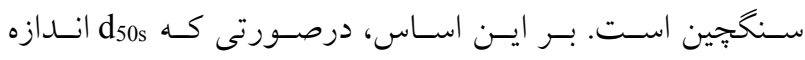

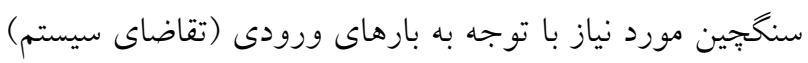

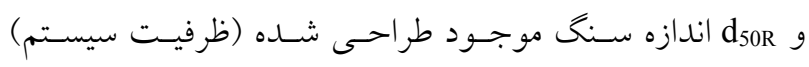

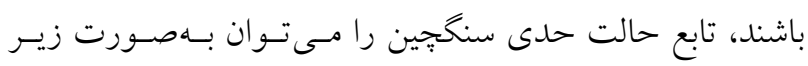
تعريف كرد: - م

$\mathrm{g}(\mathrm{X})=\mathrm{d}_{50 \mathrm{R}}-\mathrm{d}_{50 \mathrm{~S}}$

همان كونـه كـه از ايـن رابطـه مشـخص اسـت شكسـت لايـهـ

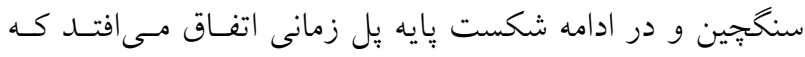

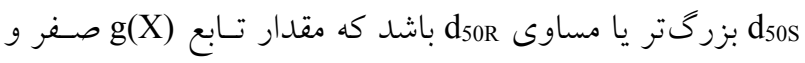
يا منفى شود. در تحقيق حاضر از رابطه (1) براى تعيسين انـدازه

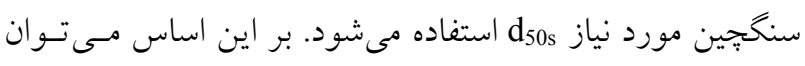
رابطه (V) را بهصورت زير نورد نياز

$$
\begin{aligned}
\mathrm{g}(\mathrm{X}) & =\mathrm{d}_{50 \mathrm{R}}-\lambda^{-0.8} \times\left(\frac{\rho_{\mathrm{s}}}{\rho}-1\right)^{-0.8} \times \mathrm{U}^{1.6} \times \\
& \mathrm{g}^{-0.8} \times \mathrm{y}^{-0.2} \times \mathrm{B}^{-0.8} \times[\mathrm{B} \times(1-\operatorname{Sin} \theta)+\mathrm{L} \times \operatorname{Sin} \theta]^{1.2} \\
& \times \mathrm{K}_{\mathrm{c}}{ }^{-0.8} \times \mathrm{K}_{\mathrm{g}}{ }^{-0.8}
\end{aligned}
$$

با داشتن تابع حالت حدى، مرحله بعدى تحليل قابليت اطمينـان

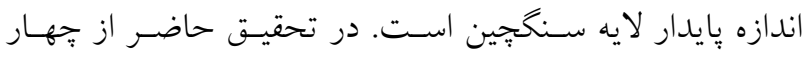

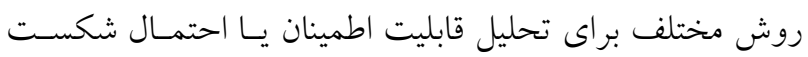
سنگجين به قرار زير استفاده مى مشود.

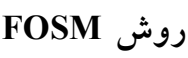
اين روش يكى از اولين روشهاى تحليل قابليـت اطمينـان بــود 
احتمال تجمعى معكـوس مربـوط بـهـ فراسـنجههـاى اسـتاندارد

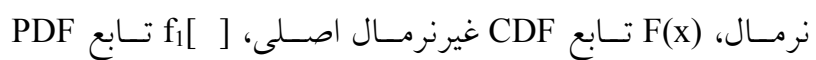

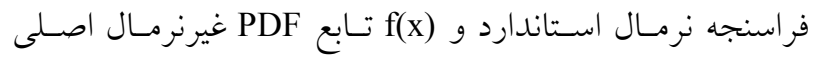

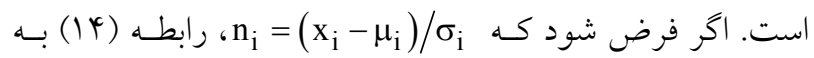
صورت زير نوشته مىشود:

$\beta=\min _{\mathrm{x} \in \mathrm{F}} \sqrt{\left[\mathrm{n}^{\mathrm{T}}\right][\mathrm{R}]^{-1}[\mathrm{n}]}$

درنهايت شاخص $\beta$ را مىتوان در يك مسئله بهينهسازى محدود

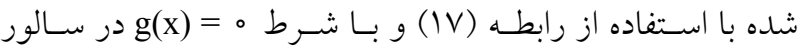
اكسل محاسبه كرد. اين كار با تغيير مقادير ni انجام مى گيرد.

\section{روش MCST}

روش MCST بـهـهـورت بـــــآورد نمونسههــاى مختلفـى از فراسنجههاى تصادفى بايه با توجه به ويزگى هاى احتمـالاتى هر يكى و قرار دادن اين نمونهها در تابع حالت حدى انجـام مى گيرد. همان كونه كه بيشتر بيان شد شكست هنخـامى رخ

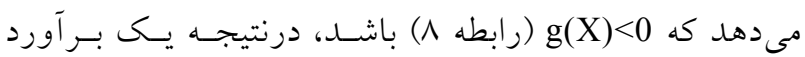

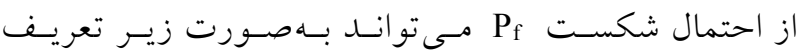

$\mathrm{P}_{\mathrm{f}}=\frac{\mathrm{N}_{\mathrm{f}}}{\mathrm{N}}$

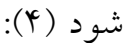

كه در آن N شمار خرخههاى شبيهسازى اسـت كـه >0 (X) و

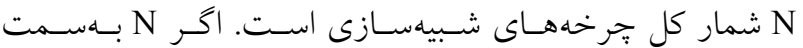

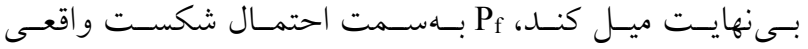

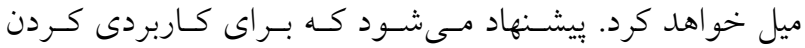

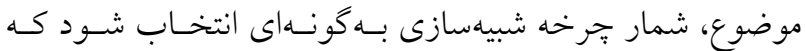
ضـريب تغييـرات Coefficient of Variation (COV) (نسـبت هندات

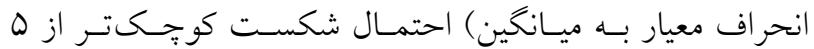

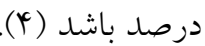

\section{تأثير اعمال ضريب همبستخى}

ضريب همبستكى شاخصى اسـت رياضسى كـه جهـت و مقــدار رابطةٌ بين دو فراسنجه را توصسيف مسىكنـل. بـين دو فراسـنجه همبستكى وجود دارد درصورتى كه مقـادير دو فراسـنجه شـبيه

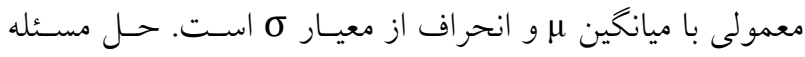
بهينهسازى بالا بهصورت سعى و خطا انجام مى گيرد كـه امكـان

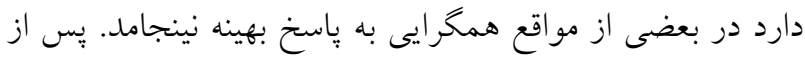

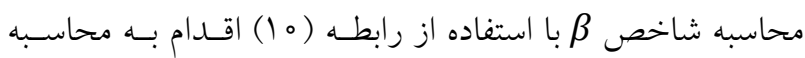
احتمال شكست مىشود.

\section{Spread sheet}

لو و تانح (10) يكى روش بهينهسازى بـا اسـتفاده از توابـع و

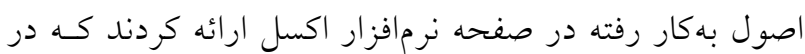

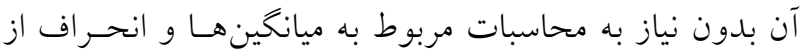
معيار نرمال معادل اقدام به محاسبه ضريب قابليت اطمينـان در

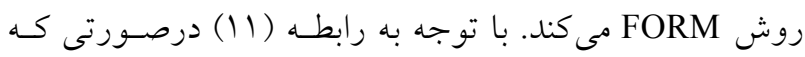

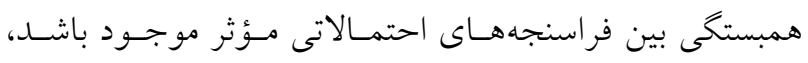

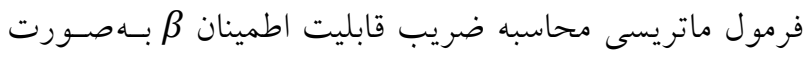
زير خواهد بود: - مان

$$
\beta=\min _{x \in F} \sqrt{(X-\mu)^{T} C^{-1}(X-\mu)}
$$

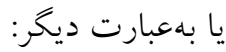

$$
\beta=\min _{x \in F} \sqrt{\left(\left(x_{i}-\mu_{i}\right) / \sigma_{i}\right)^{T} \cdot R^{-1} \cdot\left(\left(x_{i}-\mu_{i}\right) / \sigma_{i}\right)}
$$

كه در آن Xرi فراسنجه احتمالاتى i ام از بردار فراسـنجه تصـادفى

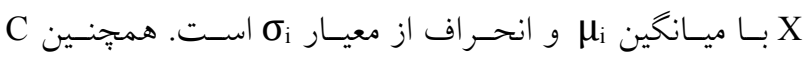
ماتريس كوواريـانس، R مـاتريس همبسـتخى و F نشـاندهنــاه ناحيه شكست است. در رابطه († |) بايد از فراسنجههاى نرمـال استفاده شود. براى فراسنجههـاى غيرنرمـال، مقـادير ميـانگين و انحراف از معيار نرمال معادل بهكونهاى محاسـبه مسى شـوند كـهـ

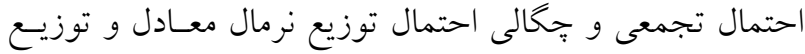
غيرنرمال مشابه باشند. در اين حالت مقدار ميانخين نرمال معادل

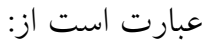

$$
\mu^{\mathrm{N}}=\mathrm{x}-\sigma^{\mathrm{N}} \varphi^{-1}[\mathrm{~F}(\mathrm{x})]
$$

و مقدار انحراف از معيار معادل عبارت است از:

$$
\sigma^{\mathrm{N}}=\mathrm{f}_{1}\left[\varphi^{-1}[\mathrm{~F}(\mathrm{x})]\right] / \mathrm{f}(\mathrm{x})
$$

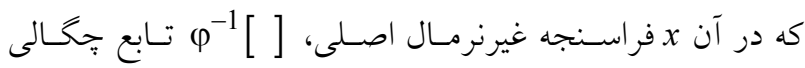



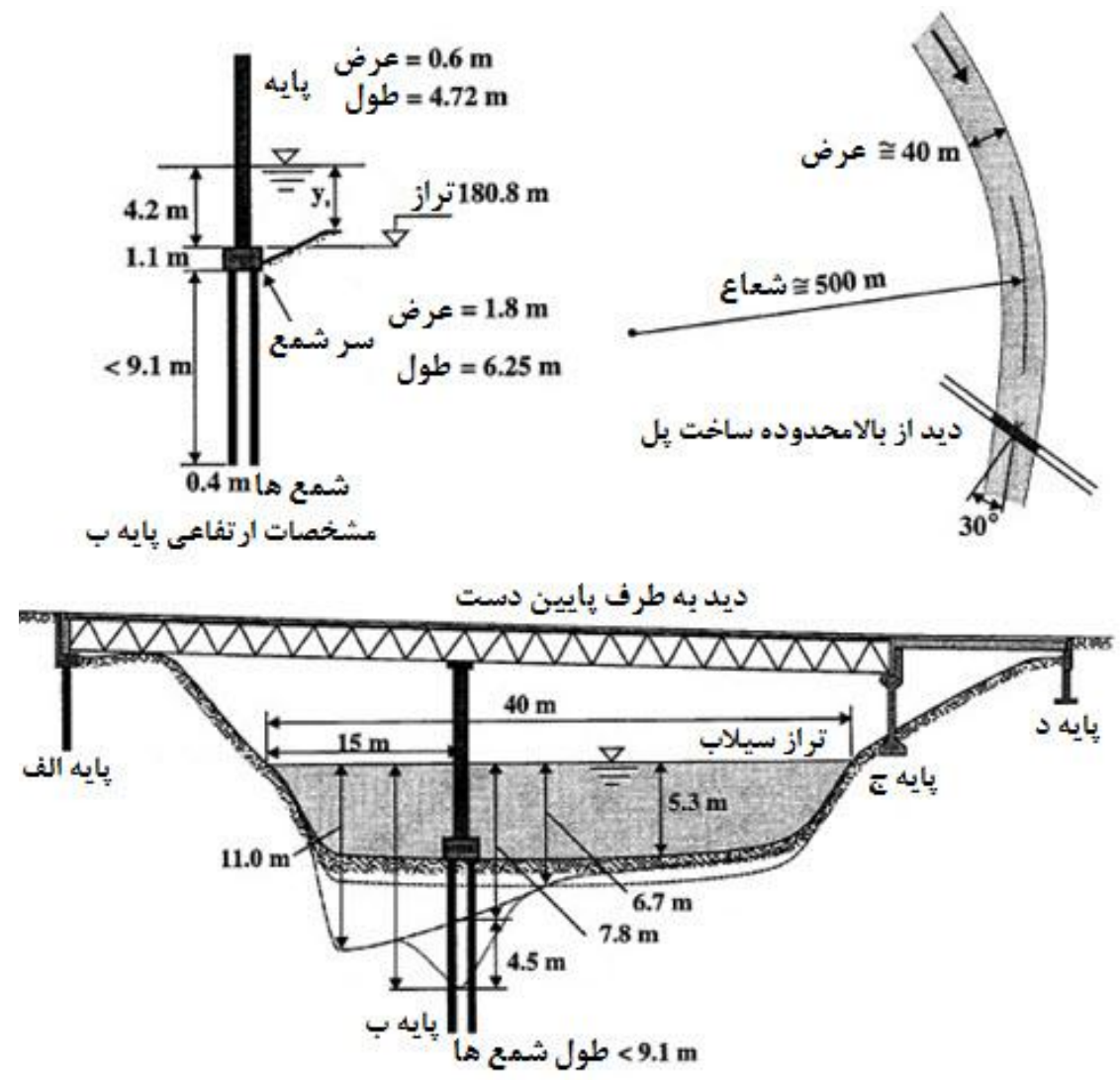

شكل r. تصوير نمادين از بل بلك مونت بههمراه دادهها و اندازههاى لازم براى طراحى سنگحِين (r)

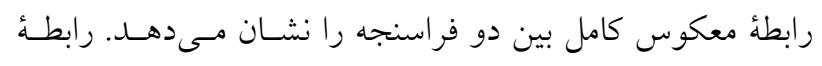

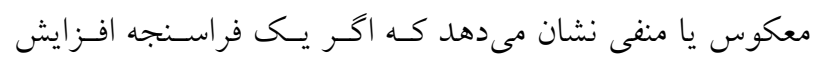

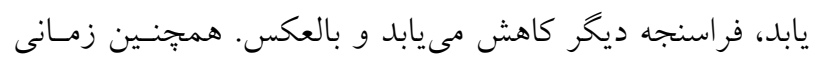

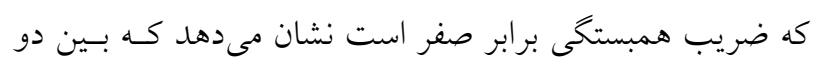
فراسنجه رابطة خطى وجود ندارد.

مطالعه موردى - بايه بِل بلكمونت در نيوزيلند

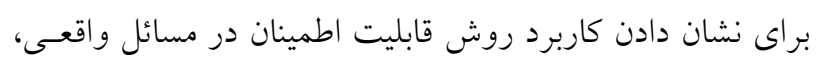

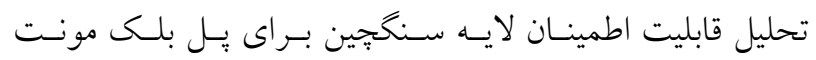

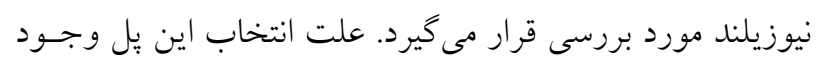

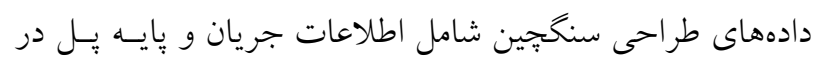

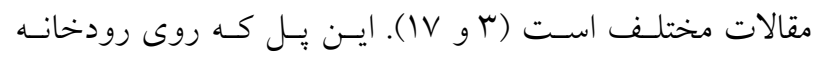

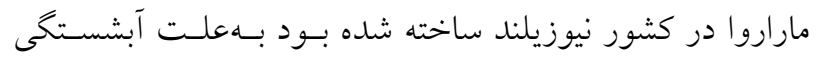

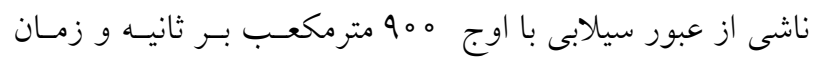

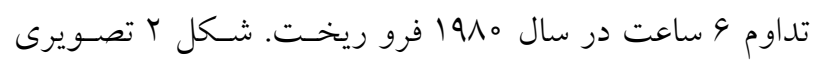

هم تغيير كند يعنى با كم يا زياد شدن يكى ديخرى هـم كـم يـا

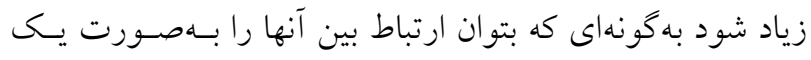

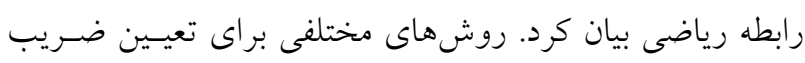



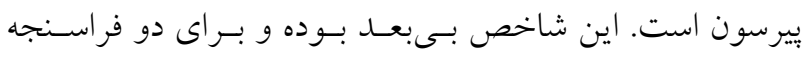

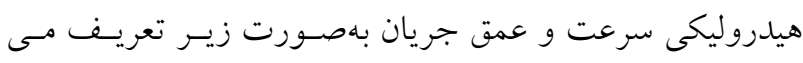
$\rho_{\mathrm{U}, \mathrm{y}}=\frac{\mathrm{E}((\mathrm{U}-\mathrm{E}(\mathrm{U}))(\mathrm{y}-\mathrm{E}(\mathrm{y})))}{[\operatorname{Var}(\mathrm{U}) \cdot \operatorname{Var}(\mathrm{y})]^{1 / 2}}$

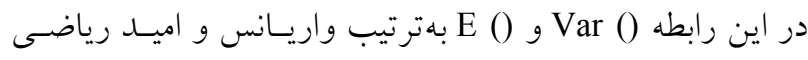

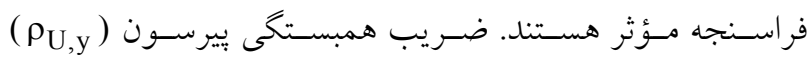

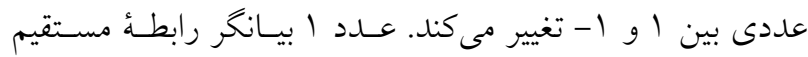

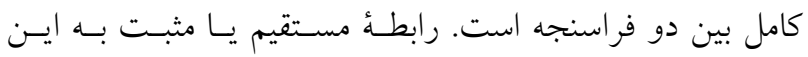

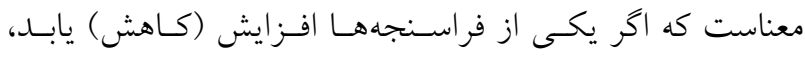

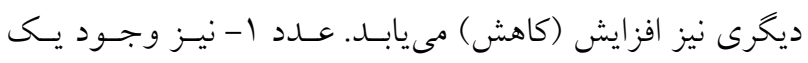


جدول ا. محدوده دادههاى مؤثر بر اندازه سنگجين محافظ در اطر اف بايه بِل مربوط به بِل بلك مونت نيوزيلند

\begin{tabular}{|c|c|c|c|c|c|}
\hline $\mathrm{COV}$ & $\mu$ & مرجع & نوع توزيع & فر اسنجه & رديف \\
\hline oopt & $1 \circ \circ Y / 0$ & فرض شده & يكنو اخت & $\rho_{\mathrm{w}}\left(\mathrm{Kg} / \mathrm{m}^{3}\right)$ & 1 \\
\hline O/OYY & TVOO & فرض شده & يكنو اخت & $\rho_{\mathrm{s}}\left(\mathrm{Kg} / \mathrm{m}^{3}\right)$ & r \\
\hline L/T & $\mathrm{V} / \mathrm{A}$ & $(y)$ & نرمال & $\mathrm{y}(\mathrm{m})$ & r \\
\hline o/rYq & $r / M$ & (IV) & نرمال & $\mathrm{U}(\mathrm{m} / \mathrm{s})$ & t \\
\hline$\circ / \circ 0$ & $0 / 9$ & (IV) & نرمال & $\mathrm{B}(\mathrm{m})$ & 0 \\
\hline$\circ / \circ \Delta$ & $Y / V T$ & فرض شده & نرمال & $\mathrm{L}(\mathrm{m})$ & 9 \\
\hline$\circ / \circ 0$ & r。 & $(10)$ & نرمال & $\theta\left(^{\circ}\right)$ & V \\
\hline $0 / 1$ & $\mu / \Lambda$ & $(10)$ & نرمال & $\lambda$ & $\wedge$ \\
\hline$\circ / 1$ & $\circ / \wedge 01$ & فرض شده & نرمال & $\mathrm{d}_{50 \mathrm{R}}(\mathrm{m})$ & 9 \\
\hline
\end{tabular}

همجينين مقدار ضريب برازش يوش

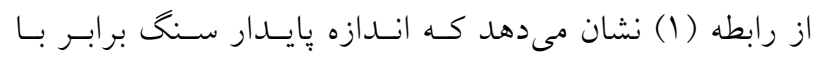

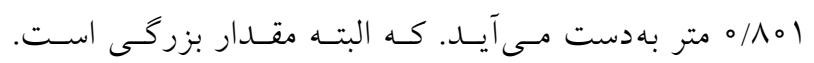
درنتيجه مى توان يِيشنهاد كرد كه از سـازههـاى محسافظ ديخــ نظير طوق استفاده كرد. نكته مهــم اينكـه بـا توجـهـ بـهـ اينكـه

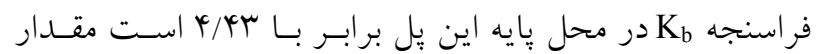

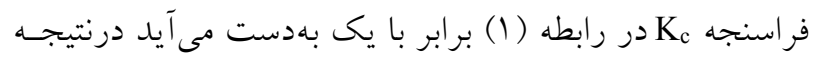
استفاده از طوق تأثيرى بر كاهش اندازه سنخجين پِيدار ندارد. براى حل اين مشكل مىتوان از سازه ديوار هدايت (شـكل ؟) براى مستقيم كردن جريان استفاده كرد در اين حالت با مستقيم شدن جريان ورودى به محل پيايه يل مقدار فراسـنجه ه

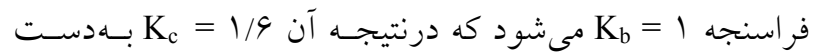

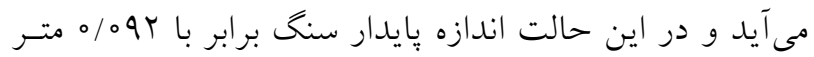
بهدست مى آيد كه بسيار كمتر از مقدار قبلى است. در واقع در شرايط استفاده از طوق و ديوار هدايت اندازه يايدار سـنكجين به ميزان ه9 درصد كاهش مىيابد كه ايسن موضـوع مسىتوانـد كمك زيادى به اقتصاد يروزه كند ولى اضـافه هزينـه ناشسى از ساخت ديوار هدايت و طوق در اين حالت بايد درنظر كرفتسه شود. بهطور كلى در اين شرايط بايد يـك تحليـل اقتصـادى و

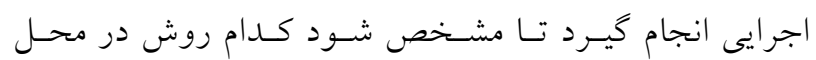
اجراى يروزه مناسبتر است.
نمادين از اين بِل را بـههمـراه اطلاعـات مختلـف بايـه و عمـق

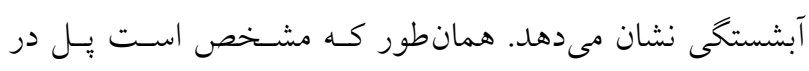
محل يك خم رودخانسه سـاخته شــده اسـت كـه ايسن موضـوع موجب تشديد اثرات جريـانهـاى جرخشى و زاويـهـ برخـورد جريان بر بتانسيل انتقال رسوب در محـل يـل مسى شـود. اخبـار غيررسمى در مورد اين بل نشان مىدهد كه بـهـلـت مشـكلات اجرايى، عمق قراركيرى شمعها كمتر از ميزان لازم محاسبه شده

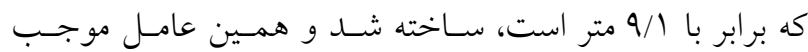
تخريب يل شد (r). با توجه به اين مشكلات اجرايسى در محـل

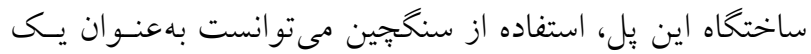
راهكار محافظت از اين يل مطرح باشد. بر اين اساس در تحقيق

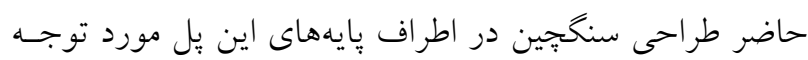
قرار مى گيرد. البته لازم به ذكر است كه روش ارائه شده در ايسن تحقيق براى هر يل ديخرى كه در مرحله طراحى قرار دارد قابـل كاربرد است. جدول ا فراسنجههاى مؤثر بههمراه توزيع آنها را براى اين يل نشان مىدهد.

\section{نتايج و بحث} طراحى قطعى اندازه سنگجِين در محل يل

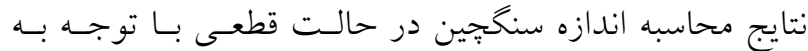
مقادير ميانخين فراسنجههاى مـؤثر ارائسه شــه در جــدول ا و 


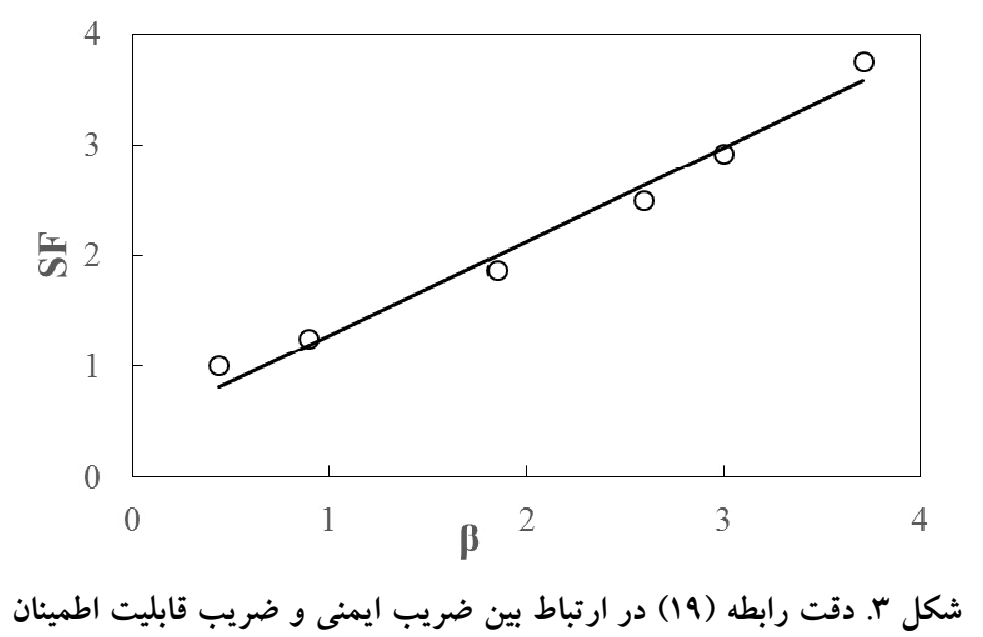

جدول r. نتايج تحليل قابليت اطمينان سنگجين با روشهاى مختلف

\begin{tabular}{|c|c|c|c|c|c|}
\hline \multicolumn{2}{|c|}{ با استفاده از طوق و ديوار هدايت } & \multicolumn{2}{|c|}{ بدون استفاده از طوق و ديوار هدايت } & \multirow{2}{*}{ روش تحليل قابليت اطمينان } & \multirow{2}{*}{ رديف } \\
\hline $\mathrm{Pf}$ & $\beta$ & $\mathrm{Pf}$ & $\beta$ & & \\
\hline $0 / 4 Y q$ & $\circ / \backslash \wedge \circ$ & $0 / 490$ & - MYQ & FOSM & 1 \\
\hline$\circ /$ Tr & $0 /$ pys & o/rYq & o/fer & FORM & r \\
\hline$\circ / \mu Y \Lambda$ & $0 /$ fys & o/rYq & o/fyt & Spread Sheet & r \\
\hline & $\circ / \mu \mu_{0}$ & o/MKY & $\circ / 4 \mu_{0}$ & MCST & r \\
\hline
\end{tabular}

بيان شد درصورتى كه شمار جرخههاى شبييهسـازى در روش

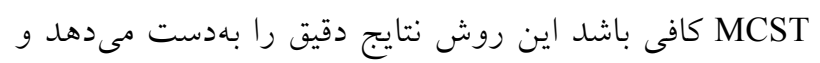

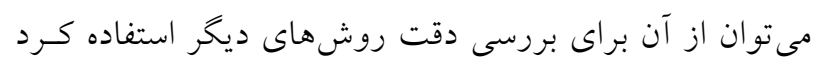

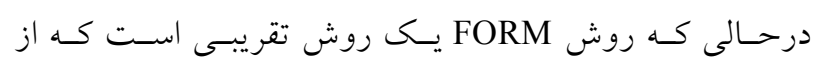

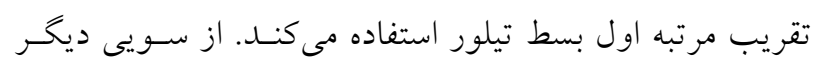

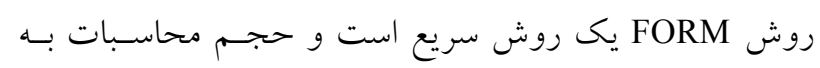
مر اتب كمترى نسبت بـه روش MCST دوش دارد. روش

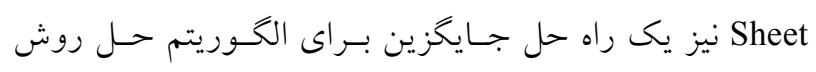

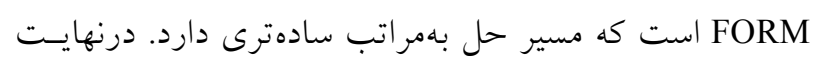

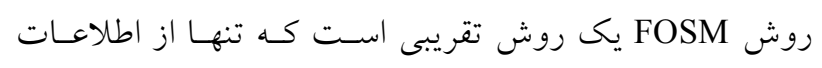

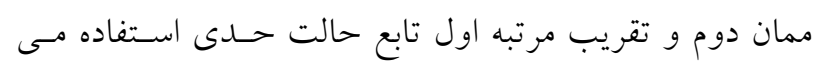

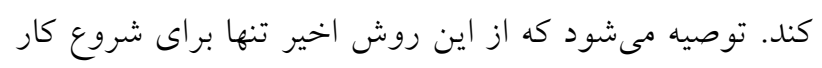

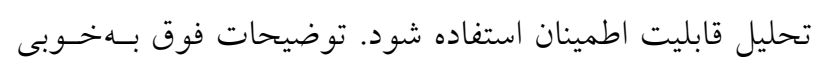

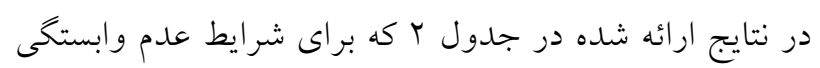
بين فراسنجههاى مؤثر محاسبه شدند، مشخص اسـت. همـان-
مقايسه روشهاى مختلف تحليل قابليت اطمينان

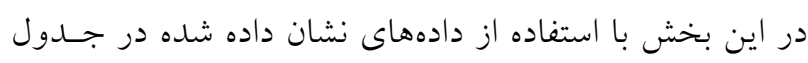
ا اقدام به محاسبه فراسنجه قابليت اطمينان و احتمال شكست بـان

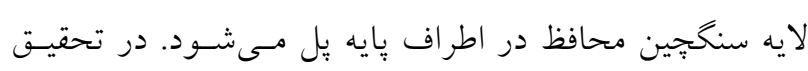

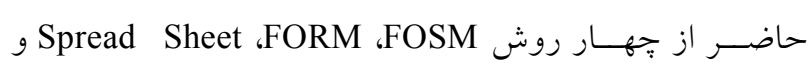

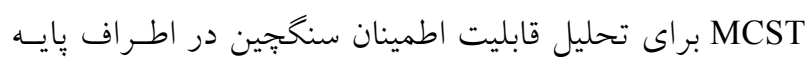

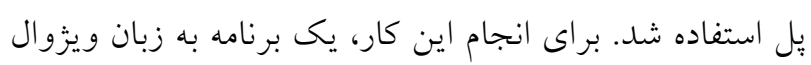

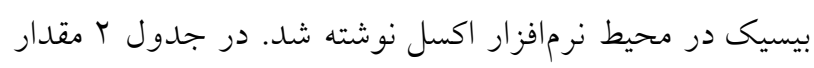

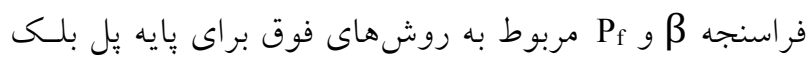

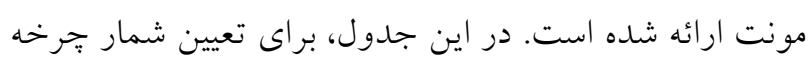
شبيهسازى در روش MCST از احتمال شكست روش و شرايط هo COV(Pf

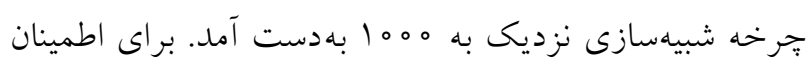

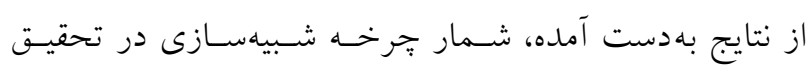

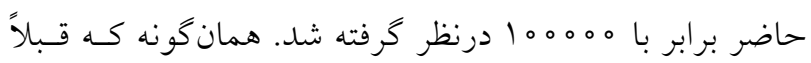


هيدروليكى لايه سنگحِين استفاده مىشود. اين ضرايب با توجـهـ

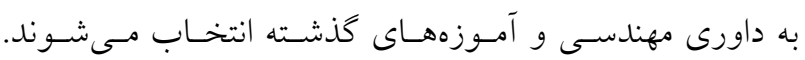

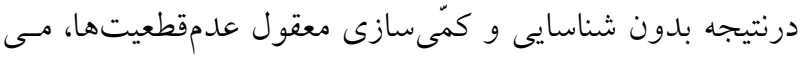

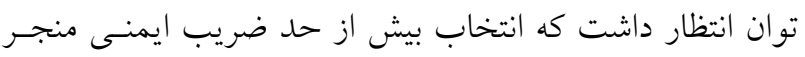

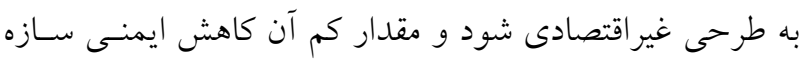

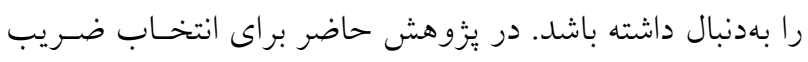

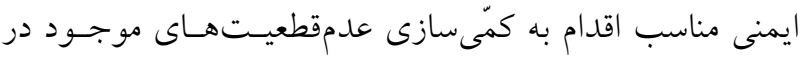

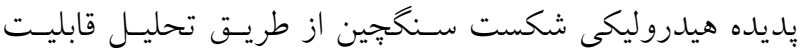

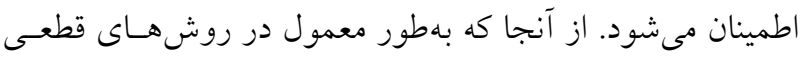
از ميانخين دادهها (جدول () استفاده مىشود با استفاده از رابطـهـ (1) مىتوان نتيجه كرفت كه ضـريب ايمنسى مربـوط بــه انــازه

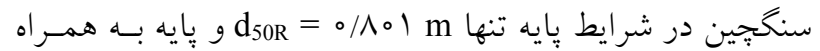

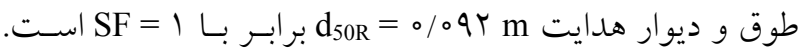

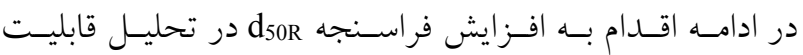

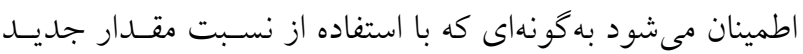
آن به مقدارهاى فوق مسى تـوان بـه مقــدار ضـريب ايمنسى (SF)

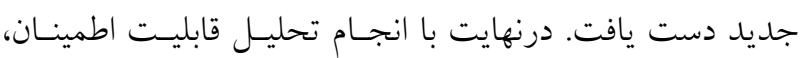

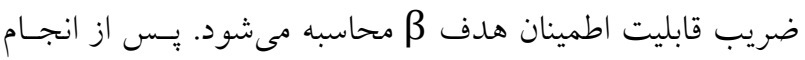

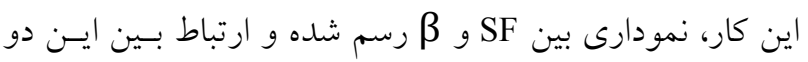

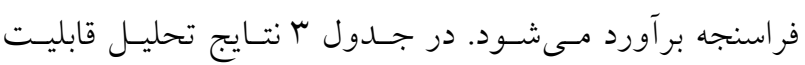

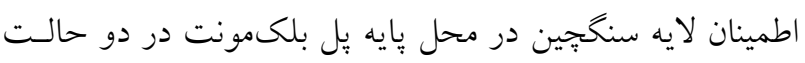

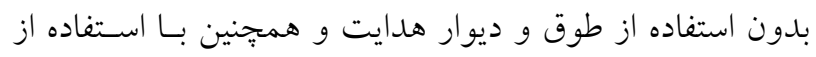
طوق و ديوار هدايت با استفاده از تحليل قابليت اطمينـان مرتبـهـ

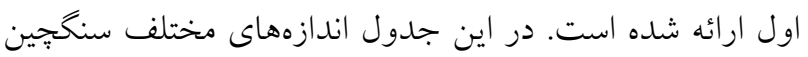

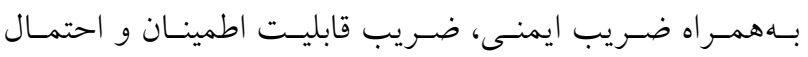
شكست متناظر ارائه شده اسـت. ضــايب ايمنسى بــا اسـتفاده از

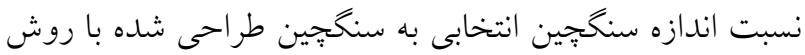

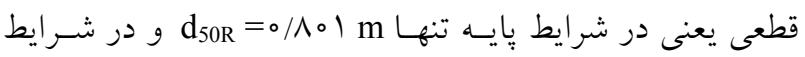

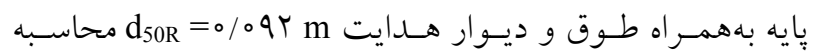
شدند. همجنين براى محاسبه ضر ايب قابليت اطمينان و احتمـال

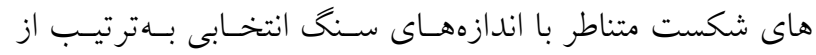

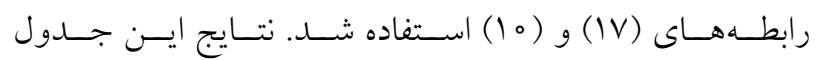

كونه كه در جدول Y مشخص است نتسايج بـهدسـت آمـده از

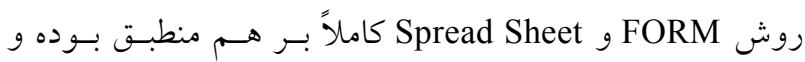

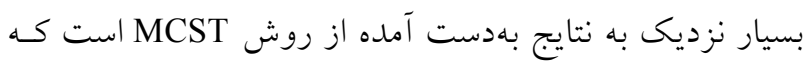

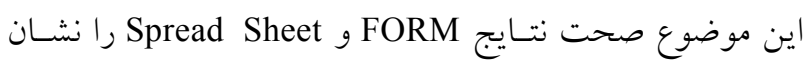

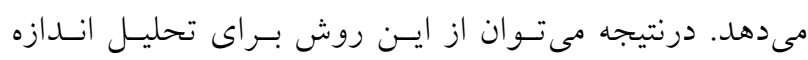

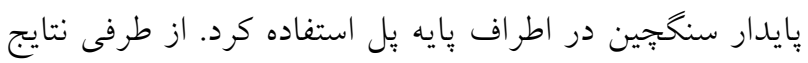
روش FOSM اختلاف بهنسبت زيادى با روشهاى ديخر دارد

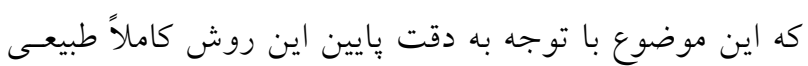

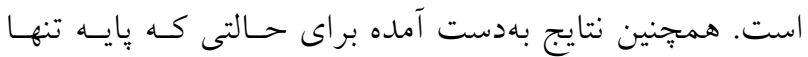

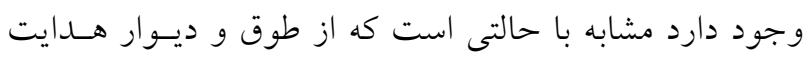
در اطراف يايه استفاده شود.

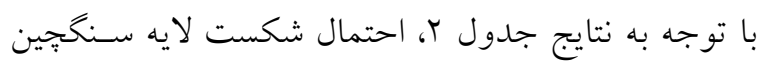
محاسبه شده با استفاده از رابطه (1) و بـهكـار گيسرى ضـريب

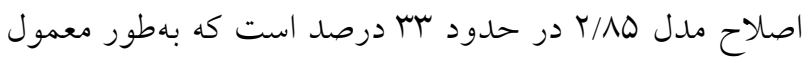

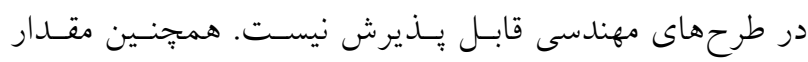

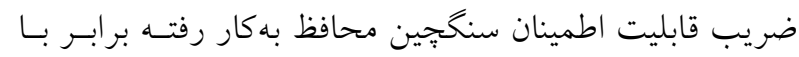

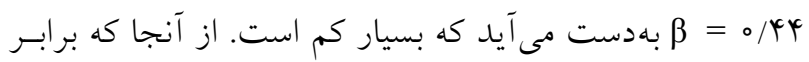
نظر كميته ايمنى سازه ضريب قابليت اطمينان هدف يـا مـورد

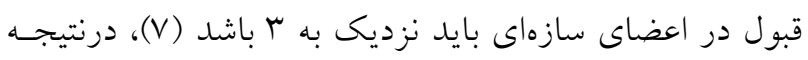

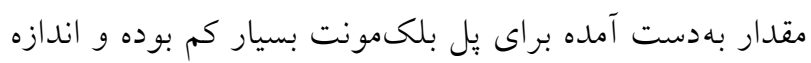

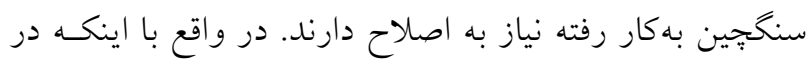
محاسبه اندازه سنكجين از مقادير ميانخين فراسنجههـاى مـؤثر

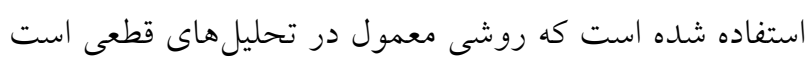

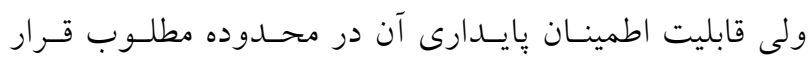

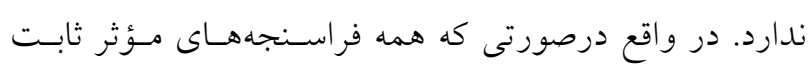

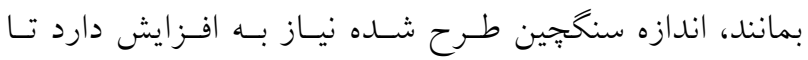

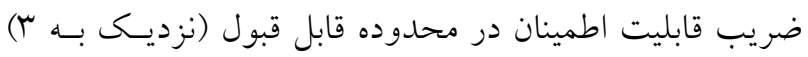
قرار كيرد.

\section{ارائه ضريب ايمنى بر مبناى تحليل قابليت اطمينان}

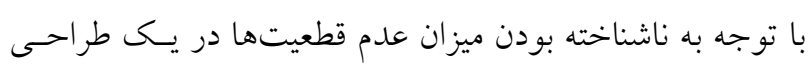

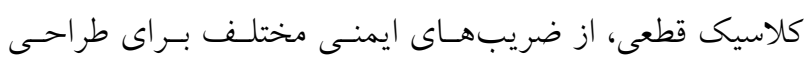


جدول r. نتايج تحليل قابليت اطمينان لايه سنگجِين در اطراف بايه بِل بلك مونت

\begin{tabular}{|c|c|c|c|c|c|}
\hline \multirow{2}{*}{$\mathrm{P}_{\mathrm{f}}$} & \multirow{2}{*}{$\beta$} & \multirow{2}{*}{ SF } & با استفاده از طوق و ديوار هدايت & بدون استفاده از طوق و ديوار هدايت & \multirow{2}{*}{ رديف } \\
\hline & & & $\mathrm{d}_{50 \mathrm{R}}(\mathrm{m})$ & $\mathrm{d}_{50 \mathrm{R}}(\mathrm{m})$ & \\
\hline $0 / 4+y$ & $\circ / 4 y$ & 1 & .094 & $\circ / \wedge \cdot 1$ & 1 \\
\hline$\circ / 1 \wedge \Delta$ & $\circ / 194$ & $1 / T 0$ &.$/ 110$ & 1 & r \\
\hline $0 \%$ rt & $1 / \wedge \Delta$ & I/AV & $\circ / I V T$ & $1 / 0$ & r \\
\hline$\circ / \circ \circ \Delta$ & $r / \Delta 9$ & $r / \Delta_{\circ}$ & $\circ / \pi$. & r & $r$ \\
\hline $0 \% 01$ & r & r/AT & $0 / 499$ & $r / M Y$ & 0 \\
\hline $0 / 0001$ & $r / N 1$ & $r / v Q$ &.$/ M Y Q$ & $r$ & 9 \\
\hline
\end{tabular}

كـاهش مقاومـت اصـطكاكى در آن لحــاظ شـود، Y) اجــــاى

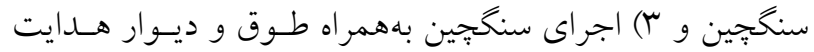
يكى را انتخاب كند. درنهايت با توجه به دادههاى ارائه شـده در جدول זّمىتوان رابطهاى خطى بين دو فراسنجه مهم طراحىها

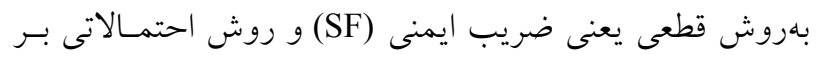

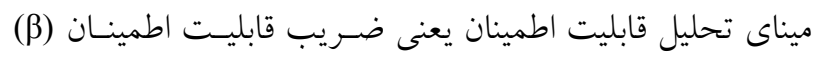

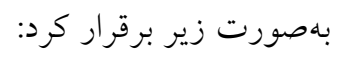

$\mathrm{SF}=0.85 \beta+0.43$

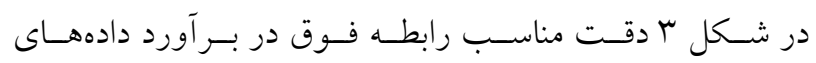

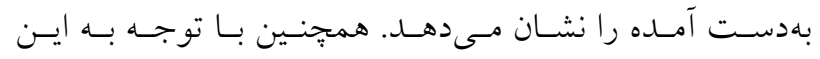
رابطه مشخص مىشود كه با افزايش ضـريب قابليـت اطمينـان،

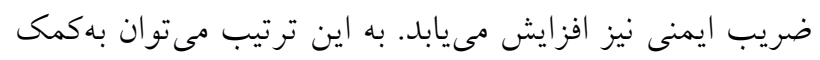

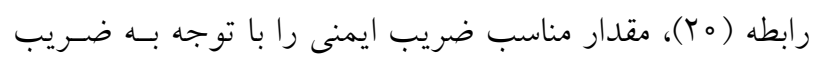

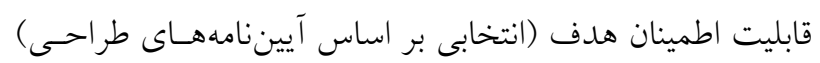

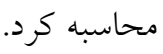

\section{بررسى ارتباط مابين فراسنجههاى مؤثر بر طراحى سنگجِين}

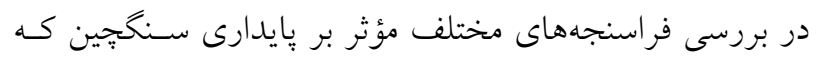

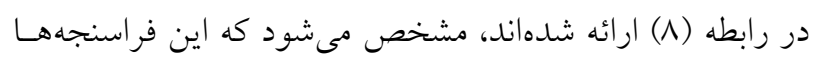

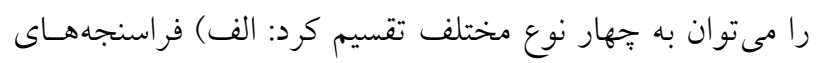

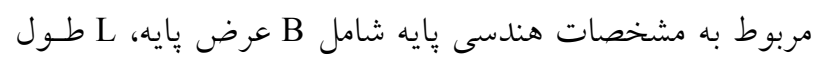

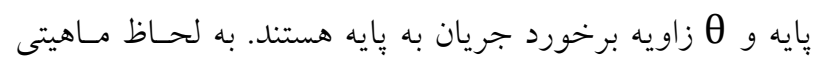

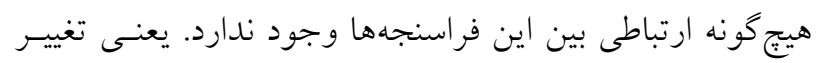

نشان مسيدهـــ كـهـ مقـــار ضـريب قابليـت اطمينـان و احتمــال

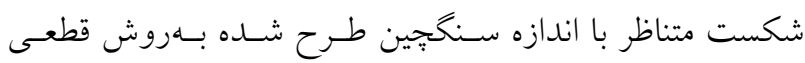

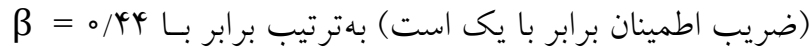
محاسبه مىشـود كـه مقــادير غيرقابـل قبـولى در P Pf

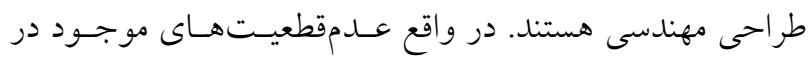

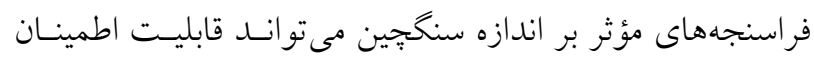

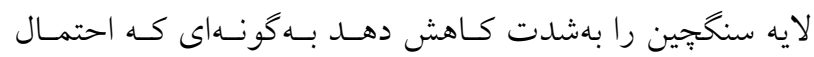

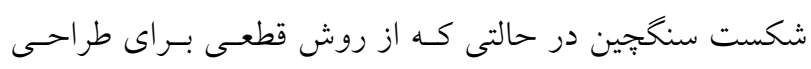

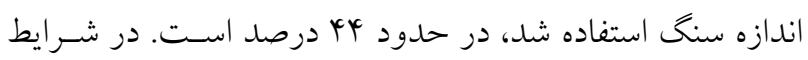

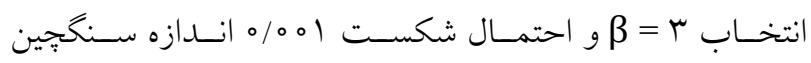

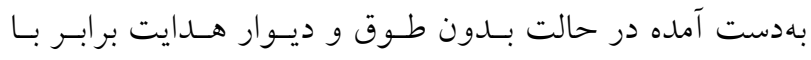

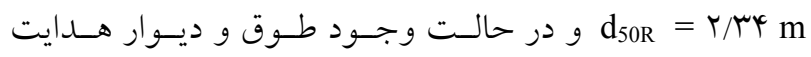
d50R = هستند. مقدار متناطر ضـريب ايمنس در ايسن

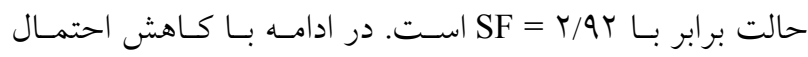
شكست سنگ

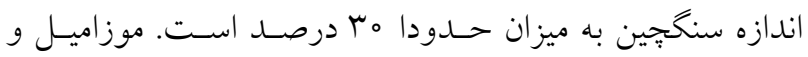

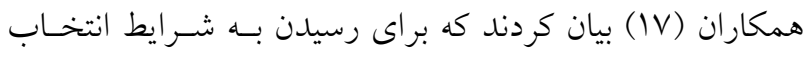

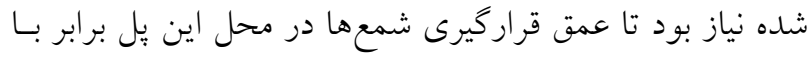

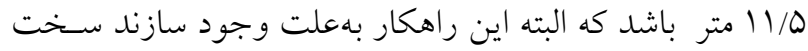

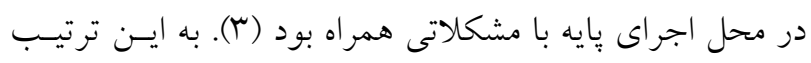

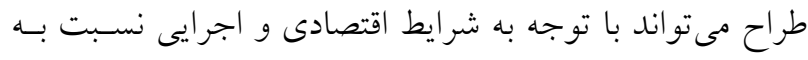

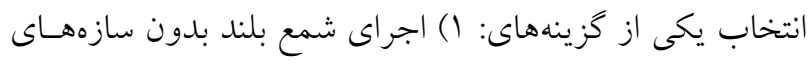

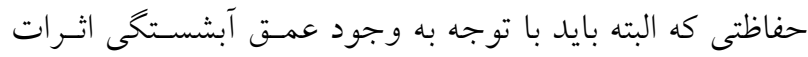


ايسن موضـوع نشـاندهنـده همبسـتخى بـالاى مسـتقيم ايـن دو فراسنجه است. در ادامه براى بررسى اعمال ضـريب همبســــى بـر قابليـت

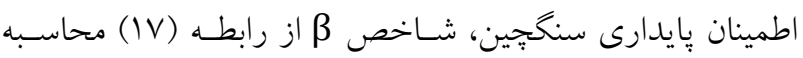
مىشود. در اين معادله ماتريس ضرايب همبستخى بهصورت زير

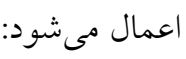

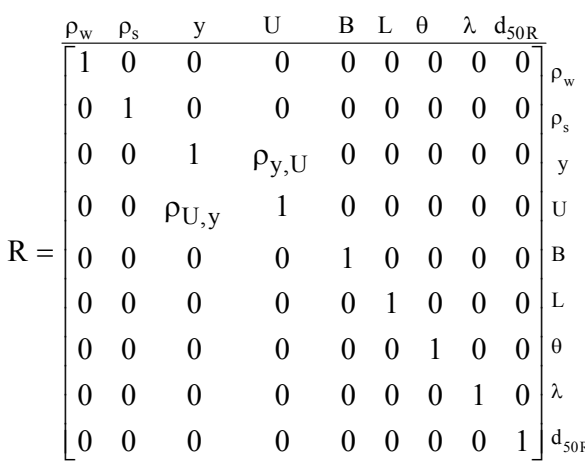

در اين ماتريس مربعى مقادير همبستخى فراسنجههاى مـؤثر بــر اندازه سنگجِين قرار دارند كه در بالا و سـمت راسـت مـاتريس مشخص شدهاند. مقادير صفر در اين ماتريس نشاندهنــده عـدم همبستخى و مقادير يك نشاندهنده همبستخى كامل هسـتند. در واقع هـر فراسـنجه بـا خــود همبسـتكى كامـل و مسـتقيم دارد.

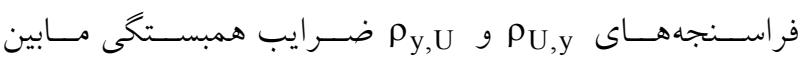
فراسنجههاى U و y را نشان مىدهند كه با توجه به خصوصيات مفهوم كواريانس با هم برابرند (†). در ادامه براى بررسى اثر ضريب همبستخى بين فراسـنجههـا بر قابليت اطمينان يايدارى سنخجين در اطراف يايه يّل، ماتريس R در رابطه (IV) قرار داده شد و مقدار شاخص قابليت اطمينان م در اين شرايط محاسبه شد. جدول \& مقادير مختلـف ضـريب ק را با توجه به مقادير مختلف ضريب همبسـتخى مى دهل. با توجه به نتايج محاسبات انجـام شــه مقــار ضـريب م در محدوده 9/, محدودههاى بيشتر، محدوده اين ضريب از مقــار صـفر (عـدم همبستخى بين دو فراسنجه) تا مقدار يـك در جـدول \& بر درنظـر

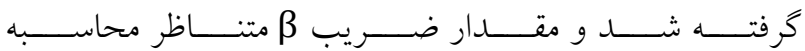

يكى موجب تغيير در ديخرى نمىشود. درنتيجه مىتوان ضريب

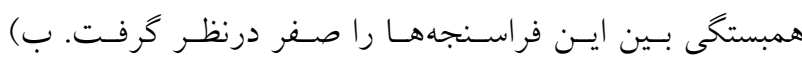
فراسنجه مربوط به شرايط بستر حفاظت شده شـامل هـ سنخجين است كه مشخصهاى از نوع سنخ استخراج شده است و ارتباطى به فراسنجههاى ديخر ندارد. ج) فراسنجه مربـوط بــ

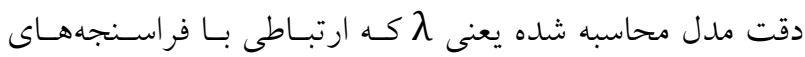
Uيخر ندارد. د) فراسنجههاى مربوط به شرايط جريـان شـامل

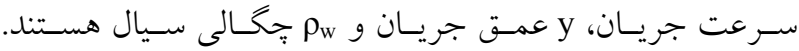
بررسى بين اين فراسنجهها نيز نشان مىدهد كه ارتباط معنادارى بين U سرعت جريـان و y عمـق جريـان وجــود دارد. بـهـ ايسن ترتيب بين تمامى فراسنجههاى مؤثر بر شكست سنگجِين ارتباط بـين U و ل معنــادار اسـت كـهـ لازم اسـت مقــدار ايسن ارتبـاط مشخص شود. ارتباط بـين فراسـنجههـاى هيـدروليكى جريـان شـامل U و y را مسى تــوان بـا روشهـاى مختلـفـ در مهندسىى رودخانه تعيين كرد. يكى از محبـوبتــرين روشهــا اسـتفاده از معادله مانينخ است كه براى يك كانال روباز با مقطع ذوزنقـهاى

$$
\text { بهصورت زير تعريف مىشود: }
$$

$\mathrm{U}=\frac{1}{\mathrm{n}} \cdot \mathrm{R}_{\mathrm{h}}{ }^{2 / 3} \cdot \mathrm{S}^{1 / 2}=\frac{\mathrm{S}^{1 / 2}}{\mathrm{n}} \cdot\left(\frac{(\mathrm{w}+\mathrm{yz}) \mathrm{y}}{\mathrm{w}+2 \mathrm{y} \sqrt{1+\mathrm{z}^{2}}}\right)^{2 / 3}$

كه در آن n ضريب مانينخ، S شيب طولى رودخانه و R شعاع هيدروليكى مقطع كه با توجه بـه شـكل مقطع تـابعى از عمـق جريان y و بقيه فراسنجههاى مقطع است. همانخونه كه در شكل r مشخص است مقطع يكى رودخانه را مىتـوان بـهــكل يـك ذوزنقه فرض كرد. در رابطه (Y) مقـدار R برحسـب y عمـق جريان، w عرض كف كانال و z شيب جداره Z z واحد افقى در برابر ا واحد عمودى) براى يك مقطع ذوزنقه ارائه شده اسـت. درصورتى كه مقدار z = باشد مقطع بهصورت مستطيلى است. در تحقيق حاضر با توجه به مقادير مختلف z اقدام بـه محاسـبه ضريب همبستكى دو فراسنجه U و y يعنى ( $)$ ئس از رابطه (19) شد. نتايج نشان داد كه با تغيير مقدار z از صفر تا r، مقدار ضريب همبستخى از 9/ه تا 91/ه تغيير مى كند به كونسه اى كه با افزايش مقدار Z، ضريب همبستكى نيز افزايش مىيابد. 


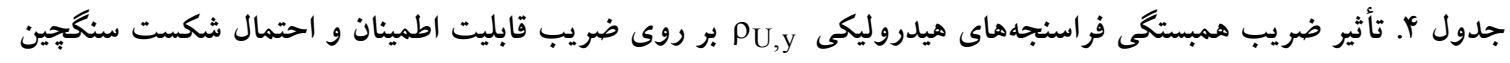

\begin{tabular}{|c|c|c|c|}
\hline Pf & $\beta$ & $\rho_{U, y}$ & رديف \\
\hline $0 / \mu \mid k$ & ०/४^G & 1 & 1 \\
\hline هاب/ & - MAN & $0 / 9$ & r \\
\hline$\circ / \mu \backslash \Lambda$ & $\circ / \mathbb{F} V \mu$ & $\circ / V$ & $\mu$ \\
\hline IMYI & o/say & $\circ / 0$ & r \\
\hline O/MYG & $0 / 401$ & $0 / r$ & 0 \\
\hline o/Mrq & o/per & 。 & 9 \\
\hline
\end{tabular}

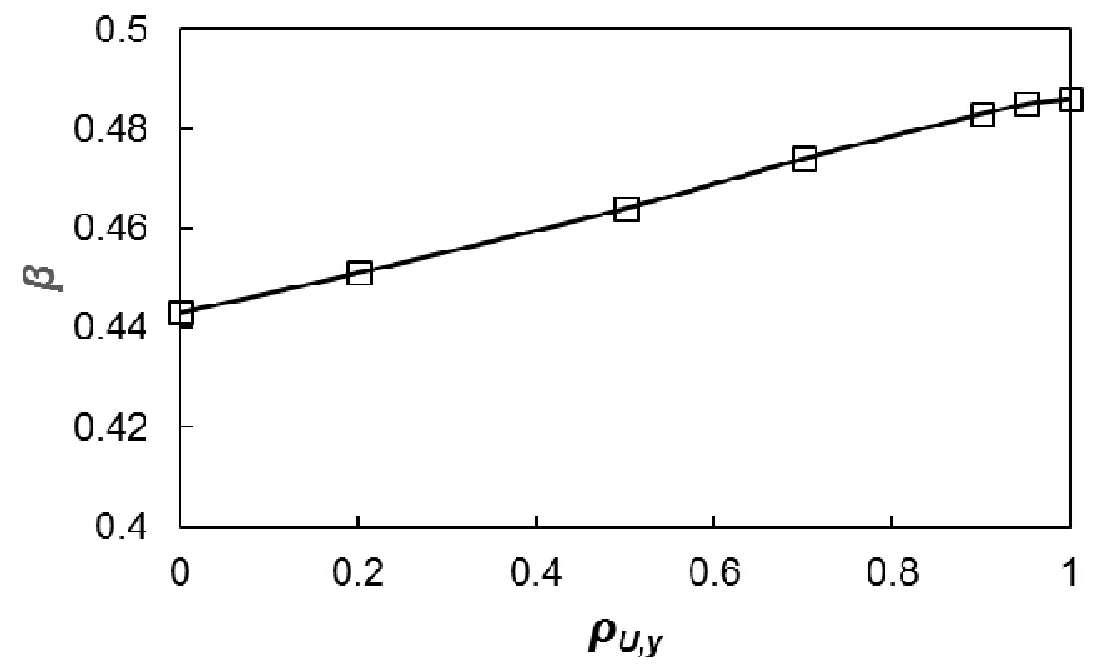

شكل fا. تغييرات ضريب همبستكى هيدروليكى P,y بر روى ضريب قابليت اطمينان

كمّىسازى عدم قطعيتهـاى موجـود در يـك مسـئله مهندسى مطـرح اسـت. در ايـن روش بــا اسـتفاده از علــم احتمــالات، اطلاعات مفيدى در مـورد يايـدارى و يـا شكسـت يـك سـازه مهندسى بهدست مى آيد. در مقاله حاضـر مطالعـه طراحسى لايسه.


شرايط واقعى بر اساس روش تحليل قابليـت اطمينـان صـورت

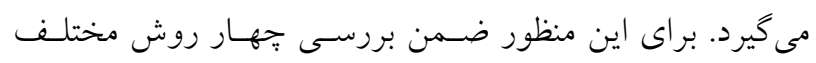

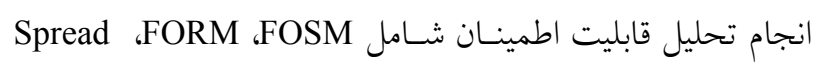
Spread sheet درنهايت با استفاده از روش، و sheet يــ روش جــايكزين بــراى حــل كلاسـيك روش FORM

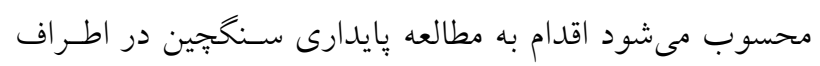

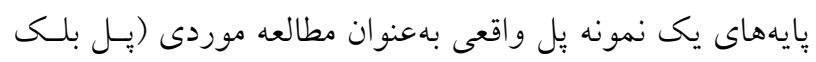

شد. همجنين در شكل † تغييرات ضـريب $\beta$ نسـبت بـه مقـدار

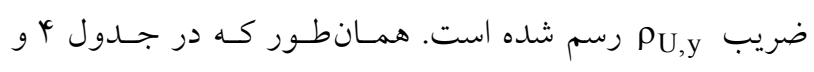
شكل Y مشخص است بـا افـزايش ضـريب همبسـتخى مقدار ضريب م افزايش يافته و احتمال شكست Pـاهش مسى

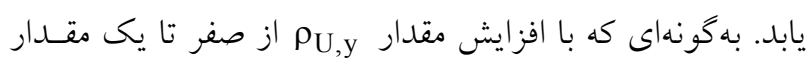
ضريب م به ميزان حدوداً ه درصــ افـزايش مسىيابـد. بـه ايسن ترتيب نتيجهذيرى مهم تحقيق حاضر نشـان مسىدهــ كـه عـدم اعمال ضريب همبسـتخى هيـدروليكى موجــب مسى شـود نتـايج تحليل قابليت اطمينان با تغيير كمى در جهت ايمنى قرار كيرد. تتيجه كيرى روش تحليل قابليت اطمينان بهعنوان يـك ابـزار مناسـب بـراى 


$$
\begin{aligned}
& \text { ضريب همبستخى بين فراسنجههاى مـؤثر بـر انـدازه ســخَحِين }
\end{aligned}
$$

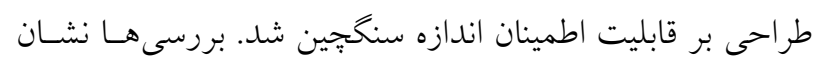

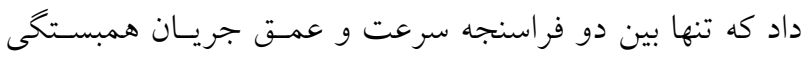

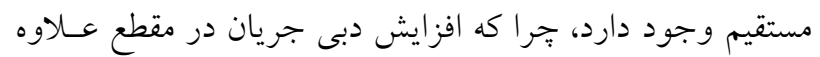

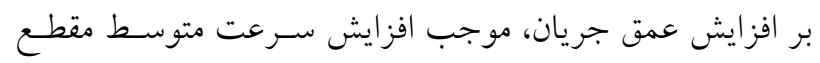

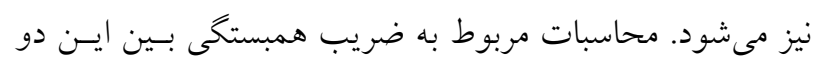

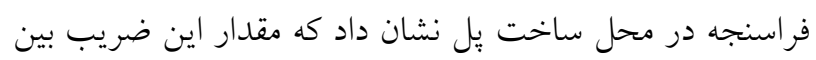

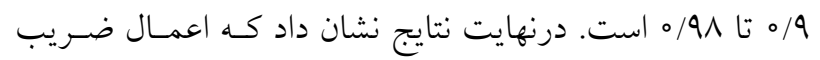

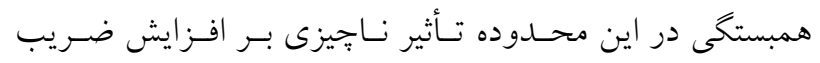

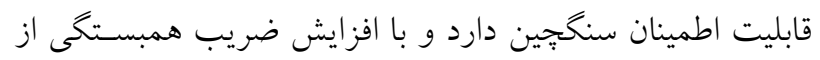

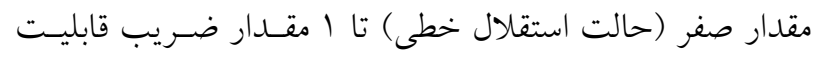

$$
\begin{aligned}
& \text { اطمينان به ميزان } 9 \text { درصد افزايش مى يابد. } \\
& \text { تشكر و قدردانى } \\
& \text { اين ثزوهش با حمايت مالى دانشخاه تربيت دبير شـهيد رجـايى }
\end{aligned}
$$

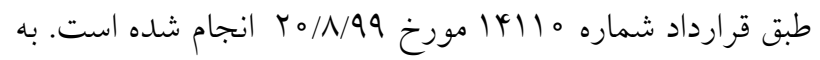

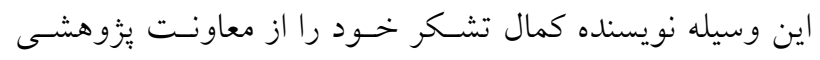

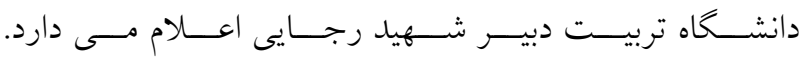

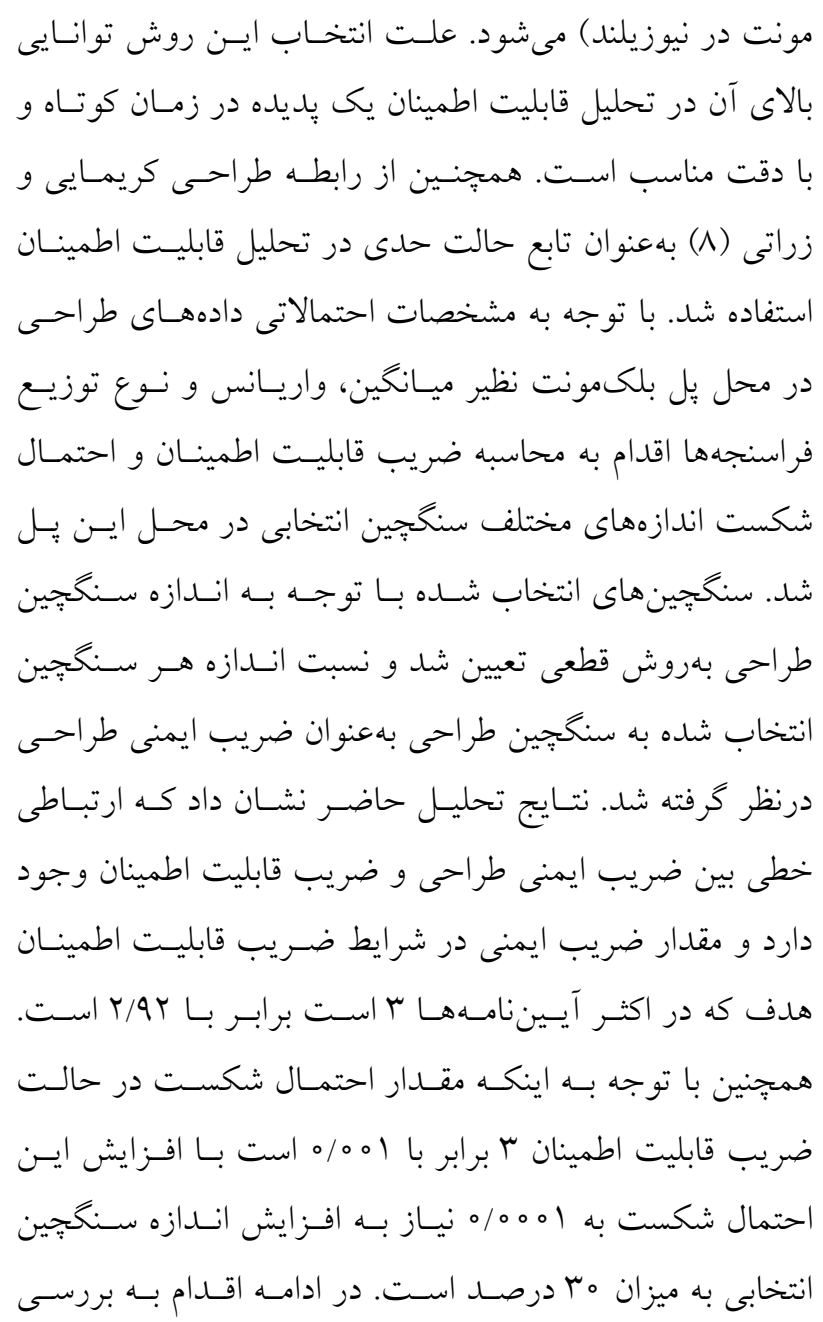

\section{منابع مورد استفاده}

1. Arneson, L. A., L. W. Zevenbergen, P. F. Lagasseand and P. E. Clopper. 2013. Evaluating scour at bridges (5th edition). Hydraulic Engineering Circular, No. 18, FHWA-HIF-12-003.

2. Briaud, J. L., P. Gardoni and C. Yao. 2014. Statistical, Risk, and Reliability Analyses of Bridge Scour. Journal of Geotechnical and Geoenvironmental Engineering 140(2): 04013011. doi:10.1061/(ASCE)GT.1943-5606.0000989.

3. Coleman, S. and B. Melville. 2001. Case study: New Zealand bridge scour experiments. Journal of Hydraulic Engineering 127(7): 535-546.

4. Halder, A. and S. Mahadevan. 2000. Probability, Reliability and Statistical Methods in Engineering Design. John Wiley \& Son, P: 161, New York.

5. Johnson, P. and D. Dock. 1998. Probabilistic bridge scour estimates. Journal of Hydraulic Engineering 124(7): 750754.

6. Johnson, P. and S. Niezgoda. 2004. Risk-based method for selecting bridge scour countermeasures. Journal of Hydraulic Engineering 130(2): 121-128.

7. Joint Committee on Structural Safety (JCSS). Available online at: http://www.jcss.ethz.ch/.

8. Karimaei Tabarestani, M. and A. Zarrati. 2013. Design of stable riprap around aligned and skewed rectangular bridge piers. Journal of Hydraulic Engineering 139(8): 911-916.

9. Karimaee Tabarestani, M., A. Zarrati, M. Mashahir and E. Mokallaf. 2015. Extent of riprap layer with different stone sizes around rectangular bridge piers with or without an attached collar. Scientia Iranica 22(3): 709-716.

10. Karimaei Tabarestani, M. and A. Zarrati. 2019. Reliability analysis of riprap stability around bridge piers. Journal of Applied Water Engineering and Research 7(1): 79-88. 
11. Karimaei Tabarestani, M., A. Salamatian and M. Panahi. 2020. Component and system-level reliability analysis of riprap layer around bridge pier in clear water condition. ISH Journal of Hydraulic Engineering. DOI:10.1080/09715010.2019.1711206.

12. Karimaei Tabarestani, M. 2020. Study on stability and sensitivity analysis of protective riprap layer placed around bridge pier by using reliability analysis theory. Journal of Hydraulic 14(4): 51-68. (In Farsi).

13. Lagasse, P. F., P. E. Clopper, L. W. Zevenbergen and L. G. Girard. 2007. Countermeasures to Protect Bridge Piers from Scour. NCHRP Rep. 593, Transportation Research Board, NAS, Washington, DC.

14. Lauchlan, C. S. and B. Melville. 2001. Riprap protection at bridge piers. Journal of Hydraulic Engineering 127(5): 412-418.

15. Low, B. K. and W. H. Tang. 2007. Efficient spreadsheet algorithm for first order reliability method. Journal of Engineering Mechanics 133(12): 1378-1387.

16. Mashahir, M., A. Zarrati, and E. Mokallaf. 2010. Application of riprap and collar to prevent scouring around rectangular bridge piers. Journal of Hydraulic Engineering 136(3): 183-187.

17. Muzzammil, M., N. A. Siddiqui and A. F. Siddiqui. 2008. Reliability considerations in bridge pier scouring. Journal of Structural Engineering and Mechanics 28(1): 1-18.

18. Nowak, A. S. and K. R. Collins. 2000. Reliability of Structures. McGraw Hill, Singapore.

19. Pizarro, A. and E. Tubaldi. 2019. Quantification of modelling uncertainties in bidge scour risk assessment under multiple flood events. Geosciences 9(10): 445-460.

20. Rashno, E., A. Zarrati and M. Karimaei Tabarestani. 2020. Design of riprap for bridge pier groups. Canadian Journal of Civil Engineering. DOI: 10.1139/cjce-2019-0007.

21. Salamatian, A., A. Zarrati and M. Banazadeh. 2013. Assessment of bridge safety due to scour by Bayesian network. Journal of Water Management 166(6): 341-350.

22. Salamatian, A. and A. Zarrati. 2019. Reliability study on uncertainty parameters and flood duration on scouring around unprotected and protected bridge piers. ISH Journal of Hydraulic Engineering 1-9. DOI: 10.1080/09715010.2019.1570360.

23. Tafarojnoruz, A., R. Gaudio and S. Dey. 2010. Flow-altering countermeasures against scour at bridge piers: a review. Journal of Hydraulic Research 48(4): 441-452.

24. Wu, Y. and Z. Luo. 2020. Life-cycle system reliability-based approach for bridge pile foundations underscour conditions. KSCE Journal of Civil Engineering 24(2): 412-423.

25. Yanmaz, A. M. 2003. Reliability based assessment of erodible channel capacity. Turkish Journal of Engineering Environmental Science 27(4): 265-273. 


\title{
Effect of the Correlation between Hydraulic Parameters on the Reliability Analysis of a Riprap Designed around Bridge Pier
}

\author{
M. Karimaei Tabarestani ${ }^{1^{\star}}$
}

(Received: June 25-2020 ; Accepted: September 19-2020)

\begin{abstract}
One of the most common and practical methods in controlling the local scour around bridge pier is to place a protective riprap layer. Due to various uncertainties in the design of this countermeasure method, in the present study, the reliability analysis method was applied for the design of a riprap size around a real bridge pier as a case study. Therefore, four different methods including First Order Second Moment, First Order Reliability Method, Spread Sheet and Monte Carlo Simulation Technique were used to quantify the uncertainties and design of riprap size. The results showed that the probability of riprap size failure, which was calculated by the empirical equation and the use of the mean value of effective parameters in the case study, was very high, nearly $34 \%$. In the following, the relationship between safety factor and the reliability index at the site of this case study was determined. Finally, in order to achieve more realistic results, the hydraulic correlation coefficient between depth and flow velocity parameters and its effect on the probability of the riprap failure were studied. It was shown that the correlation coefficient between these two hydraulic parameters was very high and more than $90 \%$, and its maximum effect on the probability of the riprap failure was less than $10 \%$.
\end{abstract}

Keywords: Scour, Bridge pier, Riprap, First Order Reliability Method, Correlation coefficient

1. Geotechnical and Water Engineering Group, Civil Engineering Department, Shahid Rajaee Teacher Training University, Lavizan, Tehran, Iran.

Corresponding author, Email: karimaei@sru.ac.ir 